\title{
Concentration of Antioxidant Compounds from Calendula officinalis through Sustainable Supercritical Technologies, and Computational Study of Their Permeability in Skin for Cosmetic Use
}

\author{
Raquel Mur ${ }^{1}$, Elisa Langa ${ }^{2}$, M. Rosa Pino-Otín ${ }^{2}$, José S. Urieta ${ }^{1}$ (D) and Ana M. Mainar ${ }^{1, *(\mathbb{D})}$ \\ 1 GATHERS Group, Aragón Institute of Engineering Research (I3A), Universidad de Zaragoza, c/. Mariano \\ Esquillor s/n, 50018 Zaragoza, Spain; 649396@unizar.es (R.M.); urieta@unizar.es (J.S.U.) \\ 2 Campus Universitario Villanueva de Gállego, Universidad San Jorge, Autovía A-23 Zaragoza-Huesca \\ Km. 299, 50830 Villanueva de Gallego, Spain; elanga@usj.es (E.L.); rpino@usj.es (M.R.P.-O.) \\ * Correspondence: ammainar@unizar.es; Tel.: +34-976761195
}

\section{check for}

updates

Citation: Mur, R.; Langa, E.;

Pino-Otín, M.R.; Urieta, J.S.; Mainar, A.M. Concentration of Antioxidant Compounds from Calendula officinalis through Sustainable Supercritical Technologies, and Computational Study of Their Permeability in Skin for Cosmetic Use. Antioxidants 2022, 11, 96. https://doi.org/10.3390/ antiox11010096

Academic Editor: Stanley Omaye

Received: 30 November 2021

Accepted: 28 December 2021

Published: 30 December 2021

Publisher's Note: MDPI stays neutral with regard to jurisdictional claims in published maps and institutional affiliations.

Copyright: (C) 2021 by the authors. Licensee MDPI, Basel, Switzerland. This article is an open access article distributed under the terms and conditions of the Creative Commons Attribution (CC BY) license (https:// creativecommons.org/licenses/by/ $4.0 /)$

\begin{abstract}
The growing interest in the cosmetic industry in using compounds of natural and sustainable origin that are safe for humans is encouraging the development of processes that can satisfy these needs. Chlorogenic acid (CHA), caffeic acid (CAF) and ferulic acid (FA) are three compounds widely used within the cosmetic industry due to their functionalities as antioxidants, collagen modifiers or even as radiation protectors. In this work, two advanced separation techniques with supercritical $\mathrm{CO}_{2}$ are used to obtain these three compounds from Calendula officinalis, and these are then evaluated using a computational skin permeability model. This model is encompassed by the COSMO-RS model, the calculations of which make it possible to study the behaviour of the compounds in the epidermis. The results show that both CAF and FA are retained in the stratum corneum, while CHA manages to penetrate to the stratum spinosum. These compounds were concentrated by antisolvent fractionation with super-critical $\mathrm{CO}_{2}$ using a Response Surface Methodology to study the effect of pressure and $\mathrm{CO}_{2}$ flow rate. $\mathrm{CHA}, \mathrm{CAF}$ and $\mathrm{FA}$ were completely retained in the precipitation vessel, with concentrations between $40 \%$ and $70 \%$ greater than in the original extract. The conditions predicted that the optimal overall yield and enrichment achieved would be $153 \mathrm{bar}$ and $42 \mathrm{~g} / \mathrm{min}$.
\end{abstract}

Keywords: supercritical antisolvent fractionation; ferulic acid; caffeic acid; chlorogenic acid; permeability skin

\section{Introduction}

In recent years, there has been great interest in the cosmetic industry, among others, in including compounds of natural and sustainable origin in the formulation of products. This is due to, on the one hand, growing general concern related to the possible harmful effects of synthetic compounds and, on the other hand, awareness regarding the responsible consumption of these sustainable products, causing an increase in their demand. Additionally, the traditional use of plants as natural remedies, or even as cosmetics, makes them ideal candidates from which to obtain compounds that meet these requirements.

Calendula officinalis L., also known as marigold, is an aromatic herbaceous plant that belongs to the genus Calendula (Asteraceae), native to the Mediterranean countries. This genus includes approximately 25 species, of which $C$. officinalis is the only one used extensively clinically worldwide [1], traditionally as a skin remedy for dermatological problems, such as inflamed skin, redness, minor burns, or ulcers, as well as for acne or fungal eruptions [2]. Over the years, studies have demonstrated these properties, which have been duly collected in various monographs such as those by the European Scientific Cooperative On Phytotherapy (ESCOP), the European Medicines Agency (EMA) or the World Health Organization (WHO), where wound healing and anti-inflammatory actions stand 
out [3-5]. In fact, different organizations that control and regulate substances for human consumption, such as the Food and Drug Administration (FDA) or the European Chemicals Agency (ECHA), have several guidelines to regulate extracts obtained from $C$. officinalis (Directive 2004/24/EC, CFR Title 21 from FDA, etc.). They also have Chemical Abstracts Service (CAS) registry numbers (84776-23-8/70892-20-5) and European INventory of Existing Commercial chemical substances (EINEC) numbers (283-949-5/615-192-7). Regarding cosmetic use, C. officinalis is especially valuable for its assistance in cell rejuvenation, wound healing, inflammation reduction, soothing, and skin softening [6]. According to the EU cosmetic ingredient database, CosIng, the extracts of this plant have several functions as a cosmetic: skin conditioning, emollient, skin protection, fragrance, perfuming, and even flavouring [7-9]. Furthermore, it has been found that calendula oil cream can be used to protect the skin from UV radiation in the form of sunscreen cream and to maintain the natural pigmentation of the skin [10].

The potential bioactivity of $C$. officinalis has so far focused on its composition, which has been studied extensively. Important components of these plants include triterpenic saponins, flavonoids, carotenoids, sesquiterpenoids and polyphenols, among others, responsible for, for example, antimicrobial [2,11], wound and burn healing [12,13], photoprotective [14], anti-inflammatory and analgesic, [15,16] cytotoxic and immunological $[17,18]$, and even neuroprotective [19] and cardiovascular activities [20]. Within the group of polyphenols, ferulic acid (FA), caffeic acid (CAF) and chlorogenic acid (CHA) stand out due to their high antioxidant capacity [21-23], their anti-wrinkle and anti-aging effects [24-26], and the ability to modify collagen properties [27]. Furthermore, a potential role in radiation protection and photooxidation has also been reported [28-30]. All this makes them compounds of great interest for the cosmetic industry, which already has formulations that include them [31], and for this reason they will be the subject of greater interest in this work.

On the other hand, plant extracts are usually obtained using traditional techniques such as hydrodistillation or Soxhlet working at high temperatures, which can cause the degradation of the bioactive compounds of interest. In addition, these are not sustainable processes due to possible environmental contamination and the use of organic solvents that can be harmful to human health. In this regard, the use of advanced separation technologies such as that using supercritical fluids, especially supercritical carbon dioxide $\left(\mathrm{sc}-\mathrm{CO}_{2}\right)$, is of great interest for the extraction of bioactive compounds from natural sources [32,33]. This is due to its properties, since $\mathrm{CO}_{2}$ is harmless and non-flammable, and its supercritical conditions $\left(\mathrm{Pc}=74 \mathrm{bar}, \mathrm{Tc}_{\mathrm{c}}=31^{\circ} \mathrm{C}\right.$ ) are moderate enough to avoid the degradation of compounds [32]. Furthermore, it can be easily removed by reducing the pressure, becoming a gas, which generates a final extract with no residual solvent presence [34].

There are various techniques that work with $\mathrm{sc}-\mathrm{CO}_{2}$. Supercritical fluid extraction (SCE) is one of the most widely used and studied techniques for the extraction of certain compounds like monoterpenes, sesquiterpenes, phenols, etc. [35]. The most studied parameters in this technique are the temperature, pressure, $\mathrm{CO}_{2}$ flow rate, particle size of the sample, and the use of co-solvents that modify the polarity of $\mathrm{CO}_{2}$ and allow the extraction of other compounds different from the above-mentioned ones $[35,36]$. Regarding the extraction of $C$. officinalis, there have been numerous studies applying this technique to obtain compounds such as triterpenoid esters [37], triterpene triols [38], or its essential oil $[39,40]$. Another promising technique is supercritical antisolvent fractionation (SAF), which makes it possible to precipitate and concentrate bioactive compounds selectively from a solution, while the rest remain dissolved [41]. For this purpose, the solution is pumped and sprayed into a vessel, where it converges with sc- $\mathrm{CO}_{2}$ in such a way that the insoluble compounds in this new mixture (solvent $+\mathrm{sc}-\mathrm{CO}_{2}$ ) precipitate, while the still soluble ones are collected in a second vessel as a dissolution. In this way, two fractions enriched in different compounds are obtained. This technique has been used to obtain fractions rich in compounds of interest having various bioactivities such as biopesticides [42], or antiproliferative [43], antimicrobial [44], or antioxidant activity [45]. 
Taking into account the above, one of the objectives of this work is to obtain, in a sustainable way and by combining two advanced separation techniques, an extract enriched in antioxidant compounds from Calendula officinalis. To do this, first, an extraction with supercritical $\mathrm{CO}_{2}$ will be carried out to defat the plant material and facilitate obtaining the antioxidant substances. After maceration in ethanol, a study of the influence of pressure (80-160 bar) and of the $\mathrm{CO}_{2}$ flow rate $(10-60 \mathrm{~g} / \mathrm{min})$ on the SAF process will be performed. This will be performed using a Response Surface Methodology (RSM) based on Central Composite Design (CCD), which will provide the values for the studied magnitudes and the sequence to follow when doing the experiments. The compounds chosen to be concentrated on were FA, CHA and CAF, due to their antioxidant properties [21-23].

On the other hand, the fact that a compound is of natural or synthetic origin does not affect the possibility that it may have harmful or beneficial effects on people's health, so it is necessary to study its interaction with human tissues. In vivo and in vitro tests are expensive and difficult to perform, in addition to the fact that there are several regulations that strongly recommend or require the use of alternatives to animal studies (EU REACH regulation) or that even prohibit the marketing of cosmetics with ingredients tested on animals (EU Cosmetics Regulation EC 1223/2009) [46]. In this regard, in silico experimentation is of great interest, because it makes the study of the interaction of solutes with biological membranes possible, and therefore, their possible toxicity. There are various predictive models for the bioavailability of solutes based on quantitative structure-permeability relationship (QSPR) models, molecular dynamics (MD) simulation, or mechanistic models derived from first principles such as mass balance, relying on additional assumptions such as Fick's laws of diffusion [47].

In this research framework, in silico research on the interaction of solutes with biomembranes, the study of molecular mechanisms behind skin permeation stands out, since it is a tool that makes it possible to identify inappropriate ingredients that may be dangerous in a cosmetic composition $[48,49]$. One of the most innovative models is the one proposed by Schwöbel et al. [46] which is based on the use of the Conductor-like Screening model for Real Solvents (COSMO-RS). From the extensions of this model-COSMOperm, COSMOmic and COSMOplex - a computational skin model that makes it possible to calculate the permeability of different compounds in it is generated. This model was applied to study the interaction of the tracked compounds of C. officinalis, CHA, CAF, FA, with the skin and thus to calculate their permeabilities.

\section{Materials and Methods}

\subsection{Plant Material}

Calendula officinalis L. flowers were collected from an ecological cultivation in Huesca (Spain) by Valentia, an association where people at risk of social exclusion work. The plant material was dried in a dryer at room temperature. Dried Calendula flowers had an $11.29 \pm 0.48 \mathrm{wt} \%$ humidity content, determined ten times with a Sartorious model MA 40 Moisture Analyzer (Goettingen, Germany). The plant material was ground with an electric grinder and sieved with a vibratory sieve shaker (CISA model BA 300N, Barcelona, Spain). The average diameter of particles was $0.5 \mathrm{~mm}$. This was adjusted to a normal distribution according to ASAE S319.3 from the American National Standards Institute [50].

\subsection{Chemicals and Reagents}

The $\mathrm{CO}_{2}(99.9 \%)$ used in SCE and SAF was purchased from Carburos Metálicos (Zaragoza, Spain) and ethanol (99.9\%) for maceration was obtained from VWR Chemicals (Barcelona, Spain). The solvents used for HPLC analysis were ethanol (PanReac AppliChem 99.9\%, Barcelona, Spain), formic acid (PanReac AppliChem 98\%, Barcelona, Spain), acetonitrile (Scharlau 99.9\%, Barcelona, Spain) and MilliQ water $(18.2 \mathrm{M} \Omega \cdot \mathrm{cm}$, Zaragoza, Spain). The HPLC standards ferulic acid ( $\geq 99 \%)$ and caffeic acid ( $\geq 98 \%)$ were purchased from Sigma-Aldrich (Madrid, Spain), whereas chlorogenic acid (97.1\%) was procured from European Pharmacopoeia Reference Standard (Madrid, Spain). 


\subsection{Supercritical $\mathrm{CO}_{2}$ Extraction ( $S C E$ )}

In a first stage, the plant material was defatted with supercritical $\mathrm{CO}_{2}$ in a Waters laboratory scale plant (SFE-1000F-2-FMC10 System, Pennsylvania, USA). Its scheme has been published previously [51] and its main components consist of an extraction vessel of $1 \mathrm{~L}(\mathrm{E})$, and two $0.5 \mathrm{~L}$ collectors $(\mathrm{C} 1, \mathrm{C} 2)$. All three vessels were jacketed to maintain a constant temperature. The $\mathrm{CO}_{2}$ stored in a bottle was passed through a cooling bath (CB) to keep it liquid and then propelled through a pump (P2) towards E. A heat exchanger (HE) was used to ensure that the $\mathrm{CO}_{2}$ passing into $\mathrm{E}$ was above the critical temperature. Flow rate and temperature were automatically controlled, as was the pressure in $\mathrm{E}$. The pressure in $\mathrm{C} 1$ and $\mathrm{C} 2$ was controlled by manual back pressures (MBPR).

The procedure is the same as that performed in previous works [51]. The same proportion of plant material/inert glass bead was used $(100 \mathrm{~g} / 200 \mathrm{~g})$, which allows a better $\mathrm{CO}_{2}$-solid contact, and therefore facilitates better extraction. The complete extraction process consisted of 4 static-dynamic cycles and the extraction conditions were 350 bar, $40{ }^{\circ} \mathrm{C}$ in E, 90 bar, $45^{\circ} \mathrm{C}$ in $\mathrm{C} 1$ and 30 bar and $30^{\circ} \mathrm{C}$ in $\mathrm{C} 2$. The $\mathrm{CO}_{2}$ flow rate was $60 \mathrm{~g} / \mathrm{min}$. Once the machine was depressurized, the extracts collected from $\mathrm{C} 1$ and $\mathrm{C} 2$ and the plant material recovered from $\mathrm{E}$ were stored in a freezer for further experiments and analysis.

The supercritical extraction yield $\left(Y_{\mathrm{SCE}}\right)$ was calculated through Equation (1):

$$
Y_{\mathrm{SCE}}(\mathrm{wt} \%)=\left(\frac{\text { mass }(g)_{\mathrm{C} 1}+\text { mass }(g)_{\mathrm{C} 2}}{\text { mass }(g)_{\text {vegetal material }}}\right) \cdot 100
$$

where $\operatorname{mass}(g)_{\mathrm{C} 1}$ and $\operatorname{mass}(g)_{\mathrm{C} 2}$ are the mass in grams of the extract deposited in collectors $\mathrm{C} 1$ and $\mathrm{C} 2$, respectively, of the SCE device, and $\operatorname{mass}(g)_{\text {vegetal material }}$ is the initial mass in grams of the dried plant material loaded in the extractor.

\subsection{Maceration and Supercritical Antisolvent Fractionation (SAF) Processes}

Maceration with ethanol (EtOH) was performed to obtain the polar and active compounds of $C$. officinalis flowers. A $3 \mathrm{~L}$ volume of the solvent was used to macerate $300 \mathrm{~g}$ of vegetal material, previously defatted with $\mathrm{SCE}$, for $48 \mathrm{~h}$ at room temperature $\left(25^{\circ} \mathrm{C}\right)$. Then, a rotatory evaporator (Büchi R-200, Flawil, Switzerland) was used to remove the solvent and obtain the dry extract. Equation (2) indicates the formula to calculate the maceration yield:

$$
Y_{\mathrm{EtOH}}(\mathrm{wt} \%)=\left(\frac{\text { mass }_{\text {extract }}(g)}{\text { mass }_{\text {vegetal material }}(g)}\right) \cdot 100
$$

where mass plant extract $(g)$ was the mass of the solvent-free extract obtained and mass $s_{\text {vegetal material }}$ $(g)$ was the initial mass, in grams, of plant material subjected to maceration and on which the SCE process was applied.

To prepare the feed solution (FS) for each of the SAF experiments, the extract obtained (without solvent) was redissolved in ethanol at 3\% (wt \%) and filtered through Cellulose Acetate filters with a pore size of $0.22 \mu \mathrm{m}$. SAF experiments were carried out by a laboratoryscale plant (Waters, Pennsylvania, USA), the scheme of which is represented in Figure 1. The plant was equipped with a $\mathrm{CO}_{2}$ pump (P-SCF), an FS pump (P-LIQ), a $0.5 \mathrm{~L}$ precipitation vessel (PV), and a $0.5 \mathrm{~L}$ downstream vessel (DV). Temperatures and flow rates of both $\mathrm{CO}_{2}$ and FS were automatically controlled, as was pressure in PV (ABPR), but pressure in DV was controlled by manual back pressure regulator (MBPR) [52].

A typical SAF experiment starts when $\mathrm{CO}_{2}$ is pumped by P-SCF through a heat exchanger (HE) to PV and the rest of the plant. Once the selected condition of pressure, temperature and $\mathrm{CO}_{2}$ flow rate in the system have stabilised, FS is pumped into the PV through an injector (nozzle $\varnothing=100 \mathrm{~mm}$ ). In this vessel, the insoluble compounds in the supercritical mixture $\left(\mathrm{CO}_{2}+\mathrm{EtOH}\right)$ precipitate, while the soluble compounds are gathered in DV. Once the flow of FS has finished, $30 \mathrm{~mL}$ of pure ethanol is pumped to draw the remaining FS from the pipes. Finally, a flow of $\mathrm{CO}_{2}$ is maintained to eliminate the 
residual ethanol from the solid precipitated in PV. The conditions used were selected on the basis of the previous knowledge of the research group: to avoid thermal degradation, temperature in PV was fixed at $40{ }^{\circ} \mathrm{C}$; to guarantee the supercritical state of the mixture $\left(\mathrm{CO}_{2}+\mathrm{EtOH}\right)$, the FS flow rate and the FS concentration were fixed at $0.45 \mathrm{~mL} / \mathrm{min}$ and $3 \%(\mathrm{wt} \%)$, respectively, for all experiments [53]. Then the pressure in $\mathrm{PV}$ and the $\mathrm{CO}_{2}$ flow rate were studied and varied between 80 and $160 \mathrm{bar}$ and 10 and $60 \mathrm{~g} / \mathrm{min}$, respectively.

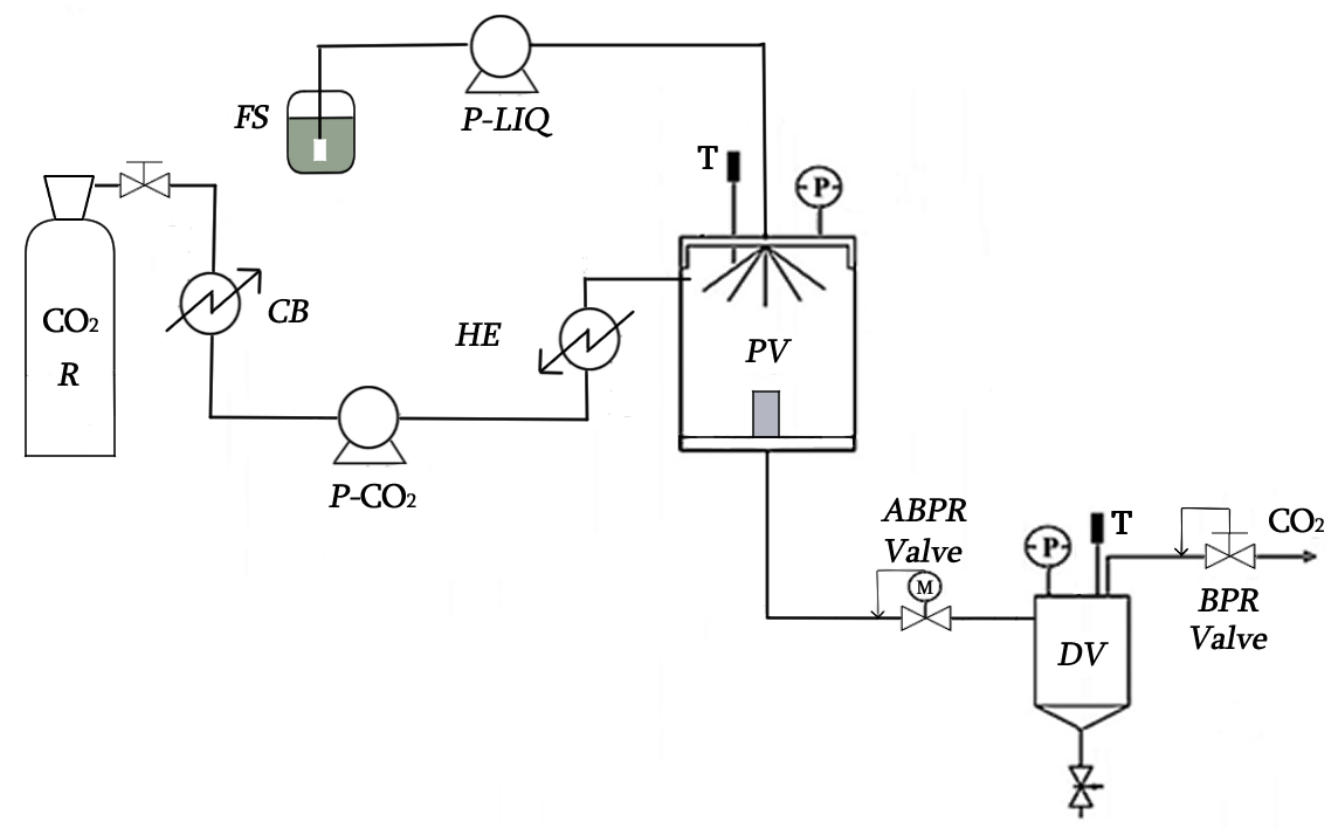

Figure 1. Scheme of the SAF equipment. Feed solution reservoir (FS); FS pump (P-LIQ); $\mathrm{CO}_{2}$ reservoir (R); cooling bath (CB); $\mathrm{CO}_{2}$ pump (P-SCF); heat exchanger (HE); precipitation vessel (PV); downstream vessel (DV); automatic back pressure regulator (ABPR); back pressure regulator (BPR); thermopar (T); Bourdon (P).

Equation (3) was used to calculate mass recovery yields for the precipitation (PV) and the downstream (DV) vessel fractions, $Y_{\mathrm{PV}}$ and $Y_{\mathrm{DV}}$, respectively, of the SAF device:

$$
Y_{\mathrm{i}}(\mathrm{wt} \%)=\left(\frac{\text { mass fraction collected }_{\mathrm{i}}}{\text { mass of extract in FS }}\right) \cdot 100
$$

where i refers to the vessel from which the mass is collected: PV or DV. The overall recovery yield of the process, $Y_{\mathrm{SAF}}$, was calculated using Equation (4):

$$
Y_{\mathrm{SAF}}(w \mathrm{t} \%)=Y_{\mathrm{PV}}(w \mathrm{t} \%)+Y_{\mathrm{DV}}(w \mathrm{t} \%)
$$

\subsection{HPLC Analysis}

The equipment used to analyse the SAF fractions of Calendula officinalis (FS, PV and DV) was a HPLC Waters ${ }^{\circledR}$ Alliance 2695 (Milford, MA, USA) with a PDA Waters ${ }^{\circledR} 2998$ (Massachusetts, USA) detector working at $\lambda=324 \mathrm{~nm}$. A reverse column $\mathrm{C} 18$ was used $\left(\right.$ CORTECS $^{\circledR} \mathrm{C} 182.7 \mu \mathrm{m}, 4.6 \times 150 \mathrm{~mm}$, (Waters ${ }^{\circledR}$, MA, USA) in conjunction with a precolumn CORTECS ${ }^{\circledR}$ Pre-column VanGuard C18 $2.7 \mu \mathrm{m}(2.1 \times 5 \mathrm{~mm})$ (Waters ${ }^{\circledR}$, MA, USA). For the chromatographic analysis, a gradient elution at $30{ }^{\circ} \mathrm{C}$ was applied with formic acid (0.1\%): Milli-water: acetonitrile. The gradient was 10:90:0 to 10:40:50 for $15 \mathrm{~min}, 10: 40: 50$ to 10:10:80 for $5 \mathrm{~min}, 10: 10: 80$ to 10:90:0 for $5 \mathrm{~min}$ and 10:90:0 for another $5 \mathrm{~min}$. The flow rate applied was $0.8 \mathrm{~mL} / \mathrm{min}$. For each sample $100 \mathrm{ppm}$ was prepared in SAF fractions (FS, $\mathrm{PV}$ and DV) and filtered through a $0.2 \mu \mathrm{m}$ filter (GH Polypropylene membrane ACRODISC $13 \mathrm{~mm}$, Waters $^{\circledR}$, MA, USA) [51]. CHA, CAF and FA standards were used to build the calibrations curves, and the conditions for analysing them were the same. In Figure 2, 
retention times can be observed for each compound: CHA $7.04 \mathrm{~min}$, CAF 7.98 min and FA $10.33 \mathrm{~min}$. The analyses of both the samples and the standards were performed in triplicate.

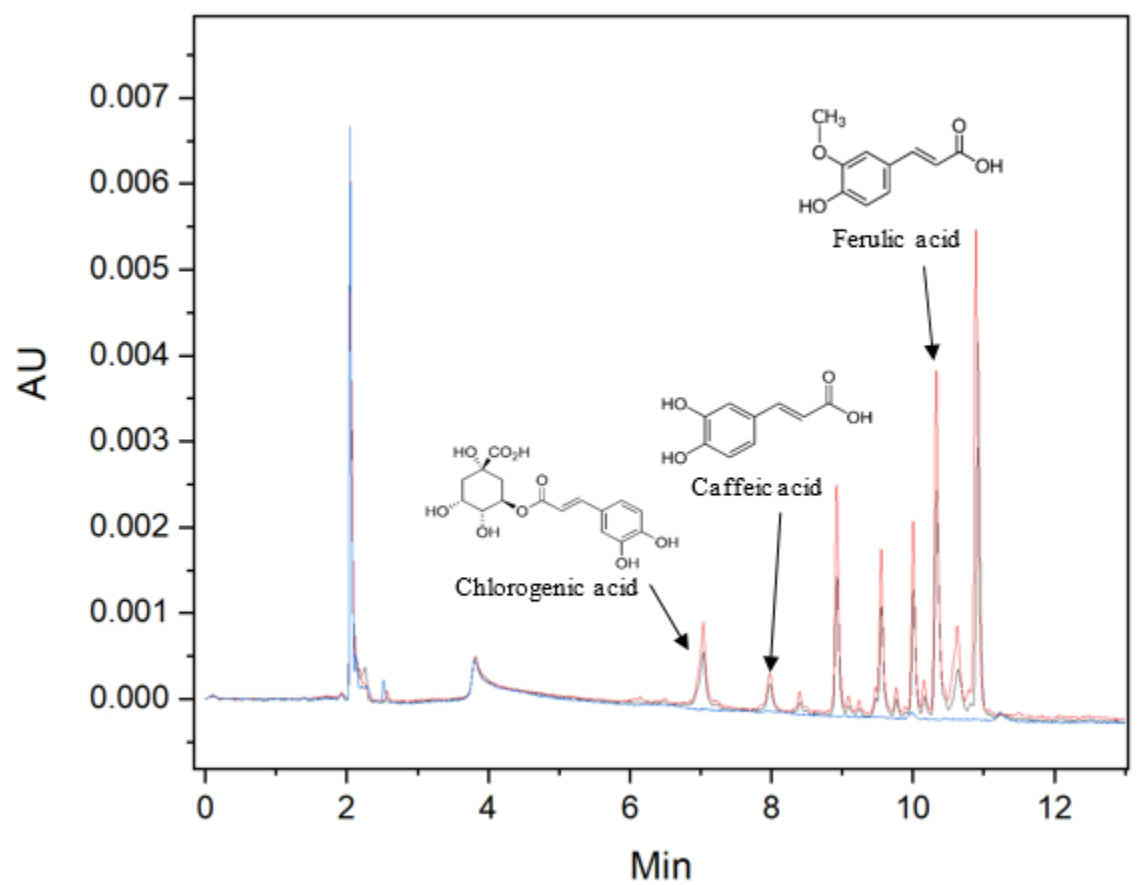

Figure 2. Chromatogram. Peak $1 \mathrm{CHA}\left(\mathrm{T}_{\mathrm{R}}=7.04 \mathrm{~min}, \lambda=324 \mathrm{~nm}\right)$, peak $2 \mathrm{CAF}\left(\mathrm{T}_{\mathrm{R}}=7.98 \mathrm{~min}\right.$, $\lambda=324 \mathrm{~nm})$ and peak $3 \mathrm{FA}\left(\mathrm{T}_{\mathrm{R}}=10.33 \mathrm{~min}, \lambda=324 \mathrm{~nm}\right)$. PV fraction: red line; FS fraction: blue line.

Equation (5) was used to calculate the concentration of a compound in each sample analysed:

$$
C_{\mathrm{i} / \mathrm{j}}(\mathrm{wt} \%)=\left(\frac{\text { mass of compound } \mathrm{i} \text { in fraction } \mathrm{j}}{\text { mass of fraction } \mathrm{j}}\right) \cdot 100
$$

where $i$ is the considered antioxidant (CHA, CAF, FA) and $\mathrm{j}$ refers to the fraction in which the compound was analysed, i.e., FS, PV or DV. Once $C_{i / j}$ had been obtained, the enrichment ratio $E_{\mathrm{i} / \mathrm{j}}$ was obtained for each compound using Equation (6):

$$
E_{\mathrm{i} / \mathrm{j}}=\frac{C_{\mathrm{i} / \mathrm{j}}}{C_{\mathrm{i} / \mathrm{FS}}}
$$

where, again, i refers to the compound analysed (CHA, CAF, FA) and $\mathrm{j}$ is PV or DV. This equation can be modified to calculate how much the PV or DV fractions are enriched in antioxidant compounds. Equation (7) shows how the enrichment ratio of all compounds analysed in PV fraction can be calculated:

$$
E_{\mathrm{ALL} / \mathrm{PV}}=\frac{C_{\mathrm{CHA} / \mathrm{PV}}+C_{\mathrm{CAF} / \mathrm{PV}}+C_{\mathrm{FER} / \mathrm{PV}}}{C_{\mathrm{CHA} / \mathrm{FS}}+C_{\mathrm{CAF} / \mathrm{FS}}+C_{\mathrm{FER} / \mathrm{FS}}}
$$

\subsection{Experimental Design and Statistical Analysis}

One of the aims in this work is to evaluate the influence of pressure and $\mathrm{CO}_{2}$ flow rate on the SAF process and then to optimize the conditions to obtain the best results on yield and enrichment ratios. To statistically study this, a response surface methodology (RMS) based on central composite design (CCD) was used. The values were set between 80 and 160 for pressure in PV, $X_{\mathrm{P}}$, and $10-60 \mathrm{~g} / \mathrm{min}$ for $\mathrm{CO}_{2}$ flow rate, $\mathrm{XQ}_{\mathrm{CO}_{2}}$. The rest of the parameters in the experiments-temperature in PV and DV, pressure in DV, and FS flow rate-were constant and were set according to previous experience to ensure the supercritical conditions of the $\mathrm{CO}_{2}$-ethanol mixture [51]. 
The mathematical model of a two variable CCD makes it possible to correlate, through Equation (8), a dependent variable, $Y$, with some independent variables, $X_{\mathrm{i}}$ and $X_{\mathrm{j}}$ :

$$
Y=\beta_{0}+\sum_{\mathrm{i}=1}^{2} \beta_{\mathrm{i}} X_{\mathrm{i}}+\sum_{\mathrm{i}=1}^{2} \beta_{\mathrm{ii}} X_{\mathrm{i}}^{2}+\sum_{\mathrm{i} \neq \mathrm{j}=1}^{2} \beta_{\mathrm{ij}} X_{\mathrm{i}} X_{\mathrm{j}}
$$

where $\beta_{0}$ is a constant coefficient, $\beta_{\mathrm{i}}$ is the linear coefficient, $\beta_{\mathrm{ii}}$ is the quadratic coefficient, and $\beta_{\mathrm{ij}}$ is an interaction coefficient. In this work, the dependant variable refers to both the yields of the SAF process $\left(Y_{\mathrm{PV}}, Y_{\mathrm{DV}}\right.$ and $\left.Y_{\mathrm{SAF}}\right)$ and the enrichment ratios of the tracked compounds (CHA, CAF and FA), while the independent variables, which are the variables under study, are pressure $\left(X_{\mathrm{P}}\right)$ and $\mathrm{CO}_{2}$ flow rate $\left(X Q_{\mathrm{CO}_{2}}\right)$.

The software used to perform the CCD design was Minitab ${ }^{\circledR} 18$. This design provides 13 random experiments, 5 of which are replicates of the central conditions according to the range levels of the variables used, shown in Table 1. This software was also used to determinate the values of each coefficient, $\beta$, in Equation (8) and their significance (when $p<0.05$ ). Finally, Minitab ${ }^{\circledR} 18$ was also used to obtain the optimal conditions for the maximum overall recovery yield $\left(Y_{\mathrm{SAF}}\right)$ and maximum enrichment ratio of the bioactive compounds (CHA, CAF, FA) $\left(Y_{\mathrm{ALL} / \mathrm{PV}}\right)$.

Table 1. Codification and levels of the two independent variables considered in the factorial design of SAF experiments.

\begin{tabular}{ccccccc}
\hline Variable & Symbol & \multicolumn{5}{c}{ Factor Levels } \\
\hline & & $\{-1.44$ & -1 & 0 & 1 & $1.44\}$ \\
\hline Pressure (bar) & $\mathrm{XP}$ & 80 & 92 & 120 & 148 & 160 \\
$\mathrm{CO}_{2}$ flow rate $(\mathrm{g} / \mathrm{min})$ & $\mathrm{XQ}$ & 10 & 17 & 35 & 53 & 60 \\
\hline
\end{tabular}

\subsection{Application of the Skin Model}

COSMO-RS is a continuum solvation model that makes it possible to calculate thermodynamic properties, generating a three-dimensional distribution of surface polarization charge-densities, $\sigma$, from optimized 3D structures of molecules [53,54]. This $\sigma$ is used, by means of an efficient statistical thermodynamic model of pairwise molecular surface interactions, to calculate the $\sigma$-potential, which gives the chemical potential of a surface segment of polarity in a particular solvent. Then, those segments are added and corrected by a combinatorial term to calculate the chemical potential of a compound in a pure or mixed solvent [53]. This can be applied, for example, to calculate the partition coefficient, $\mathrm{K}$, of a solute between two liquid phases [55].

COSMOperm is an extension of the COSMO-RS model that applies these calculations in inhomogeneous systems such as biomembranes. The COSMOmic method, included within COSMOperm, allows the calculation of partition coefficients of membranes or micelles, chemical potentials, and free energies of solutes in a layered system, which in turn makes it possible to obtain their distribution within the membrane [56-60]. The distribution of the different compounds that make up a biomembrane can be obtained using classic molecular dynamics simulations or using another extension of the COSMO-RS model, called COSMOplex. This extension generates divided liquid layers of variable composition as a representation of a biomembrane from information about its structure [61]. This makes it possible to generate a skin model with which COSMOperm works to calculate the resistance of the membranes, the permeability of individual compounds as well as their position in them, and the permeation pathway [46].

The computational skin model used in this work is based on the model proposed by Schwöbel et al. [46]. This model is based on the division of the outermost layer of the skin, the epidermis, into different compartments, or layers, with their own structure and cellular compositions [47], as can be seen in Table 2. 
Table 2. Compartments of epidermis, their abbreviations, and descriptions of each layer.

\begin{tabular}{ccc}
\hline Compartment & Abbreviation & Description \\
\hline Stratum corneum & SC & $\begin{array}{c}\text { Horny layer, the outermost layer and the } \\
\text { main barrier to permeability within the skin }\end{array}$ \\
\hline Stratum granulosum & SG & Granular layer \\
\hline Stratum spinosum & SS & $\begin{array}{c}\text { Spinous or prickle layer, release neutral } \\
\text { barrier lipids }\end{array}$ \\
\hline Stratum basale & SB & Basal layer, metabolically active \\
\hline Appendageal compartment & Shunt & $\begin{array}{c}\text { Responsible for transport of chemical } \\
\text { through the hair follicles sweat glands, and } \\
\text { sebaceous glands }\end{array}$ \\
\hline
\end{tabular}

The skin penetration model is based on a series of resistances, $R$, from which the permeability coefficient, $K_{p}$, can be calculated [62], as indicated in Equation (9).

$$
K_{\mathrm{p}}=\frac{1}{R_{\text {skin }}}
$$

where $R_{\text {skin }}$ is the overall skin resistance. To calculate $R_{\text {skin, }}$ it is first necessary to calculate the sum of all the resistances of each of the compartments that make up it, thus obtaining $R_{\text {stratified-cells }}$ as indicated by Equation (10):

$$
R_{\text {stratified-cells }}=R_{\mathrm{SC}}+R_{\mathrm{SG}}+R_{\mathrm{SS}}+R_{\mathrm{SB}}
$$

where $R_{\mathrm{SC}}, R_{\mathrm{SG}}, R_{\mathrm{SS}}$, and $R_{\mathrm{SB}}$ are the resistances of the SC, SG, SS, and SB compartments, described in Table 2, respectively. Starting from $R_{\text {stratified-cells }}$ and also taking into account the shunt pathway, the $R_{\text {skin }}$ is calculated following Equation (11):

$$
\frac{1}{R_{\text {skin }}}=\frac{1}{R_{\text {stratified-cell }}}+\frac{1}{R_{\text {shunt }}}
$$

where $R_{\text {shunt }}$ is the resistance of the shunt pathway and is kept constant $1 / R_{\text {shunt }}=2 \times$ $10^{-11} \mathrm{~m} / \mathrm{s}$.

In addition, the transport of the compounds through the compartments is calculated by Equation (12):

$$
\frac{1}{R_{\mathrm{i}}}=\frac{1}{R_{\mathrm{i}, \text { trans }}}+\frac{1}{R_{\mathrm{i}, \text { inter }}}
$$

where i refers to the compartment (SC, SG, SS or SB), $R_{\mathrm{i}, \text { trans }}$ is the mechanism of transcellular absorption (through keratin-corneocytes by partitioning into and out of the cell membrane), and $R_{\mathrm{i}, \text { inter }}$ is the mechanism of intercellular absorption (trough corneocytes in the lipid-rich extracellular regions).

The skin model was applied by COSMO-RS, using the COSMOtherm software package for each of the tracked compounds in this work: CHA, CAF and FA. First, the pre-optimized 3D chemical structures from PubChem database were obtained, and then those structures were refined by using Gaussian version 9.0 with a DFT parametrization bvp86-TZVP (cartesian coordinates for optimized geometries can be found in the Supplementary Material). The 3D structures of the compounds and their surface charge density can be observed in Figure 3. The skin model, included in COSMOplex module, was used together with the COSMOperm extension to calculate the permeabilities of each compound as well as their position in the skin model and the resistances of each compartment. 
(a)

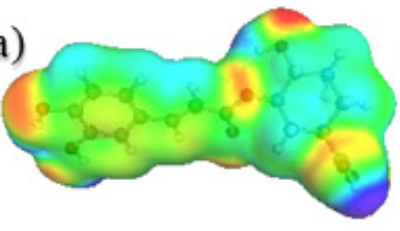

(b)
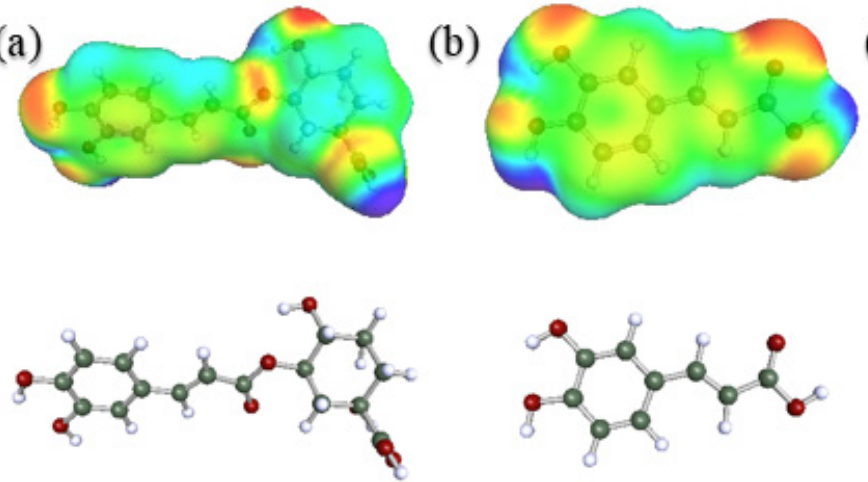

(c)
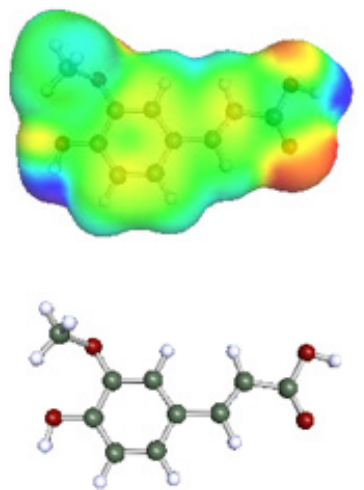

Figure 3. 3D molecular structures of (a) $\mathrm{CHA},(\mathbf{b}) \mathrm{CAF}$, and (c) FA and their charge density (electronegative zone in red, electropositive zone in blue and neutral zone in green).

\section{Results and Discussion}

\subsection{SCE and Feed Solution Preparation}

The pre-treated material, previously ground and sieved, was defatted in a first stage to facilitate the obtaining of the antioxidant fraction. This stage was usually carried out by means of maceration in hexane [41,45], but in a more recent study, supercritical extraction with $\mathrm{CO}_{2}$ was used [51]. This is due to the advantages offered by this type of extraction; since it is a non-toxic solvent, its polarity facilitates the extraction of lipophilic compounds and generates solvent-free final products because it can be easily removed by lowering the pressure. The supercritical extraction yield, $Y_{\mathrm{SCE}}$, was $8.3 \%$, which is similar to the yields obtained by D. Baumman et al. (5.5-8.3\%) [63] and A. Lopez-Padilla et al. (4.6-7.4\%) [64] under comparable SCE conditions.

The polar fraction of Calendula officinalis was obtained by maceration in ethanol (EtOH) of the plant material after the SCE. The extraction yield obtained with this ethanolic maceration, $Y_{\mathrm{EtOH}}$, was $7.2 \%$. Other authors [65] have obtained similar extraction yield $(8.0 \%)$, although the plant material was not previously defatted and the proportional mass plant $(\mathrm{g}): \mathrm{EtOH}(\mathrm{mL})$ was 1:6 instead of 1:10, as used in this work.

\subsection{SAF Yields Statistical Analysis}

Experimental values for $Y_{\mathrm{PV}}(\mathrm{wt} \%), Y_{\mathrm{DV}}(\mathrm{wt} \%)$ and $Y_{\mathrm{SAF}}(\mathrm{wt} \%)$ for every experiment are gathered in Table 3. $Y_{\mathrm{PV}}$ varied from $12.3 \%$ (run $10 ; 120 \mathrm{bar}-60 \mathrm{~g} / \mathrm{min}$ ) to $47.0 \%$ (run 1; $80 \mathrm{bar}-35 \mathrm{~g} / \mathrm{min}$ ), whereas $Y_{\mathrm{DV}}$ oscillated between 1.3\% (run 1; $80 \mathrm{bar}-35 \mathrm{~g} / \mathrm{min}$ ) and $42.8 \%$ (run 12; $148 \mathrm{bar}-53 \mathrm{~g} / \mathrm{min}$ ). It can be seen that at low pressures, $\mathrm{PV}$ yields are higher than DV yields, but this changes as the pressure increases; then, the yields equalize until $Y_{\mathrm{DV}}$ are greater than $Y_{\mathrm{PV}}$. The greatest difference was found in run 1, where $Y_{\mathrm{PV}}$ was 36 times the DV yield. Overall yields, $Y_{\mathrm{SAF}}$, varied between $31.1 \%$ (run 3; $92 \mathrm{bar}-53 \mathrm{~g} / \mathrm{min}$ ) and $73.7 \%$ (run 12; 148 bar- $53 \mathrm{~g} / \mathrm{min}$ ). As seen previously in other works [51], a full recovery of the entire mass of solutes contained in the feed solution is not possible due to the effect of two phenomena: the dragging of the most volatile components through the vent valve [66] and the deposition of materials in dead spaces.

The coefficients of Equation (8) were obtained for $Y_{\mathrm{PV}}, Y_{\mathrm{DV}}$ and $Y_{\mathrm{SAF}}$ and can be found in Table 4, along with their level of significance $p$ and the coefficient $R^{2}$ and the deviation $\mathrm{s}$ of the fitted mathematical model. The statistical analysis reveals that $Y_{\mathrm{PV}}$ depends on all terms $\left(\beta_{1}, \beta_{2}, \beta_{11}\right.$ and $\left.\beta_{12}\right)$ except the quadratic term of $\mathrm{CO}_{2}\left(\beta_{22}\right)$ and all of them are statistically significant $(p<0.05)$ except the pressure term $\left(\beta_{1}\right) . Y_{\mathrm{DV}}$ and $Y_{\mathrm{SAF}}$ depend on all terms being statistically significant only for $Y_{\mathrm{SAF}}$. For $Y_{\mathrm{DV}}$, the statistically significant terms are the pressure $\left(\beta_{1}\right)$, the quadratic term of pressure $\left(\beta_{11}\right)$, and the cross term $\left(\beta_{12}\right)$. 
Table 3. Operational conditions of pressure, $X_{\mathrm{P}}$, and $\mathrm{CO}_{2}$ flow rate $X Q_{\mathrm{CO}_{2}}$, for every run of the CCD design of the SAF process as well as the corresponding results for the yields and enrichment ratios, defined by Equations (3)-(7).

\begin{tabular}{|c|c|c|c|c|c|c|c|c|c|c|}
\hline Run & $\begin{array}{l}\text { Exp. Run } \\
\text { Order }\end{array}$ & $X_{P}($ bar $)$ & $\begin{array}{l}X Q_{\mathrm{CO}_{2}} \\
\text { (g/min) }\end{array}$ & $\begin{array}{c}Y_{\mathrm{PV}} \\
(w t \%)\end{array}$ & $\begin{array}{c}Y_{\mathrm{DV}} \\
(w t \%)\end{array}$ & $\begin{array}{c}Y_{\mathrm{SAF}} \\
(\mathbf{w t} \%)\end{array}$ & $E_{\mathrm{CHA} / \mathrm{PV}}$ & $E_{\mathrm{CAF} / \mathrm{PV}}$ & $E_{\mathrm{FA} / \mathrm{PV}}$ & $E_{\mathrm{ALL} / \mathrm{PV}}$ \\
\hline 1 & 9 & 80 & 35 & 47.0 & 1.3 & 48.3 & 0.86 & 1.19 & 0.69 & 0.79 \\
\hline 2 & 4 & 92 & 17 & 41.0 & 21.5 & 62.5 & 1.04 & 1.25 & 1.10 & 1.09 \\
\hline 3 & 10 & & 53 & 16.1 & 15.0 & 31.1 & 1.08 & 1.33 & 1.16 & 1.21 \\
\hline 4 & 13 & 120 & 10 & 26.0 & 32.2 & 58.2 & 1.51 & 1.48 & 1.67 & 1.64 \\
\hline 5 & 2 & & 35 & 26.1 & 20.3 & 46.4 & 1.53 & 1.36 & 1.55 & 1.52 \\
\hline 6 & 3 & & 35 & 22.0 & 25.8 & 47.8 & 1.52 & 1.37 & 1.54 & 1.52 \\
\hline 7 & 6 & & 35 & 18.5 & 30.0 & 48.5 & 1.40 & 1.44 & 1.56 & 1.66 \\
\hline 8 & 7 & & 35 & 15.1 & 30.5 & 45.6 & 1.59 & 1.40 & 1.73 & 1.66 \\
\hline 9 & 11 & & 35 & 13.6 & 29.6 & 43.2 & 1.72 & 1.39 & 1.70 & 1.67 \\
\hline 10 & 12 & & 60 & 12.3 & 30.4 & 42.7 & 1.14 & 1.30 & 1.25 & 1.27 \\
\hline 11 & 8 & 148 & 17 & 23.4 & 31.3 & 54.7 & 1.18 & 1.40 & 1.32 & 1.32 \\
\hline 12 & 5 & & 53 & 30.9 & 42.8 & 73.7 & 1.33 & 1.41 & 1.52 & 1.46 \\
\hline 13 & 1 & 160 & 35 & 31.1 & 34.3 & 65.4 & 1.28 & 1.37 & 1.55 & 1.46 \\
\hline
\end{tabular}

Table 4. Fitting coefficients of Equation (8) for PV, $Y_{\mathrm{PV}}, \mathrm{DV}, Y_{\mathrm{DV}}$, and overall, $Y_{\mathrm{SAF}}$, yields, chlorogenic and ferulic acid enrichment ratio in $\mathrm{PV}\left(E_{\mathrm{CHA} / \mathrm{PV}}, E_{\mathrm{FA} / \mathrm{PV}}\right.$ respectively) total enrichment ratio $\left(E_{\mathrm{ALL} / \mathrm{PV}}\right)$ as well as the significance of each term, $p$, the regression coefficients, $\mathrm{R}^{2}$, and standard deviation, $\mathrm{s}$.

\begin{tabular}{|c|c|c|c|c|c|c|c|c|c|c|c|c|}
\hline & \multicolumn{2}{|c|}{$Y_{\mathrm{PV}} / \mathrm{wt} \%$} & \multicolumn{2}{|c|}{$Y_{\mathrm{DV}} / \mathrm{wt} \%$} & \multicolumn{2}{|c|}{$Y_{\mathrm{SAF}} / \mathrm{wt}^{\circ} \%$} & \multicolumn{2}{|c|}{$E_{\mathrm{CHA} / \mathrm{PV}}$} & \multicolumn{2}{|c|}{$E_{\mathrm{FA} / \mathrm{PV}}$} & \multicolumn{2}{|c|}{$E_{\mathrm{ALL} / \mathrm{PV}}$} \\
\hline & $\begin{array}{l}\text { Coefficient } \\
\text { Value }\end{array}$ & $p$ & $\begin{array}{l}\text { Coefficient } \\
\text { Value }\end{array}$ & $p$ & $\begin{array}{l}\text { Coefficient } \\
\text { Value }\end{array}$ & $p$ & $\begin{array}{l}\text { Coefficient } \\
\text { Value }\end{array}$ & $p$ & $\begin{array}{l}\text { Coefficient } \\
\text { Value }\end{array}$ & $p$ & $\begin{array}{l}\text { Coefficient } \\
\text { Value }\end{array}$ & $p$ \\
\hline$\beta_{0}$ & 284.3 & 0.000 & -40.3 & 0.000 & 242.6 & 0.000 & -3.889 & 0.000 & -4.11 & 0.000 & -3.840 & 0.000 \\
\hline$\beta_{1}$ & -3.594 & 0.075 & 1.241 & 0.000 & -2.343 & 0.000 & 0.0796 & 0.026 & 0.0835 & 0.003 & 0.0802 & 0.004 \\
\hline$\beta_{2}$ & -2.204 & 0.019 & -1.691 & 0.833 & -3.835 & 0.003 & 0.0253 & 0.381 & 0.0160 & 0.454 & 0.0166 & 0.479 \\
\hline$\beta_{11}$ & 0.01215 & 0.000 & -0.00493 & 0.035 & 0.00717 & 0.001 & -0.000314 & 0.001 & -0.000315 & 0.002 & -0.000308 & 0.001 \\
\hline$\beta_{22}$ & - & - & 0.00898 & 0.105 & 0.00812 & 0.040 & -0.000395 & 0.034 & -0.000262 & 0.189 & -0.000264 & 0.125 \\
\hline$\beta_{12}$ & 0.01620 & 0.006 & 0.00900 & 0.058 & 0.02520 & 0.000 & - & - & - & - & - & - \\
\hline $\mathrm{R}^{2}$ & 88.28 & - & 91.26 & - & 96.74 & - & 83.00 & - & 82.91 & - & 84.54 & - \\
\hline $\mathrm{s}$ & 4.42 & - & 4.00 & - & 2.66 & - & 0.13 & - & 0.15 & - & 0.13 & - \\
\hline
\end{tabular}

In Figure 4, the contour plots corresponding to the surfaces defined by Equation (8) are shown for all yields ( $Y_{\mathrm{PV}}, Y_{\mathrm{DV}}$ and $Y_{\mathrm{SAF}}$ as $1 \mathrm{a}, 1 \mathrm{~b}$ and $1 \mathrm{c}$, respectively). In Figure $4 \mathrm{a}$, for flow rates above $12 \mathrm{~g} / \mathrm{min}$ and below $24 \mathrm{~g} / \mathrm{min}, Y_{\mathrm{PV}}$ decreases as pressure increases, while for $\mathrm{CO}_{2}$ flow rates outside this range, $Y_{\mathrm{PV}}$ first decreases and then increases as pressure increases. For a fixed pressure, an increase in $\mathrm{CO}_{2}$ flow rate causes $Y_{\mathrm{PV}}$ to decrease except for high pressures, whereas the $\mathrm{CO}_{2}$ flow rate increases, $Y_{\mathrm{PV}}$ increases. For the studied ranges of pressure and $\mathrm{CO}_{2}$ flow rates, the highest $Y_{\mathrm{PV}}$ is found at low pressures (80-83 bar) and at low $\mathrm{CO}_{2}$ flow rates $(10-16 \mathrm{~g} / \mathrm{min})$. Another maximum in $Y_{\mathrm{PV}}$ yield could be found at high pressures and $\mathrm{CO}_{2}$ flow rates (133-160 bar, 51-60 g/min). According to Figure $4 \mathrm{~b}$, $Y_{\mathrm{DV}}$ increases as pressure increases for a set $\mathrm{CO}_{2}$ flow rate. On the other hand, for a fixed pressure, a different behaviour is observed if the pressure is lower or higher than 133 bar: for low pressures, as the flow increases, $Y_{\mathrm{DV}}$ decreases, whereas the opposite effect is observed at higher pressures. In fact, the highest $Y_{\mathrm{DV}}$ is found at high pressures and $\mathrm{CO}_{2}$ flow rates (133-160 bar, 47-60 g/min). This may be due to a greater solubility of components and a higher dragging effect of the solutes towards DV. Analysing Figure 4c, it can be seen that $Y_{\mathrm{SAF}}$ follows a similar behaviour to $Y_{\mathrm{PV}}$, whereby the overall recovery of solutes from the feed solution is minimal at low pressures and high $\mathrm{CO}_{2}$ flow rates, whereas $Y_{\mathrm{SAF}}$ reaches a maximum when the two variables simultaneously reach their maximum (158-160 bar, $59-60 \mathrm{~g} / \mathrm{min}$ ) or minimum ( $80-83 \mathrm{bar}, 10-12 \mathrm{~g} / \mathrm{min}$ ) values in the intervals considered. 

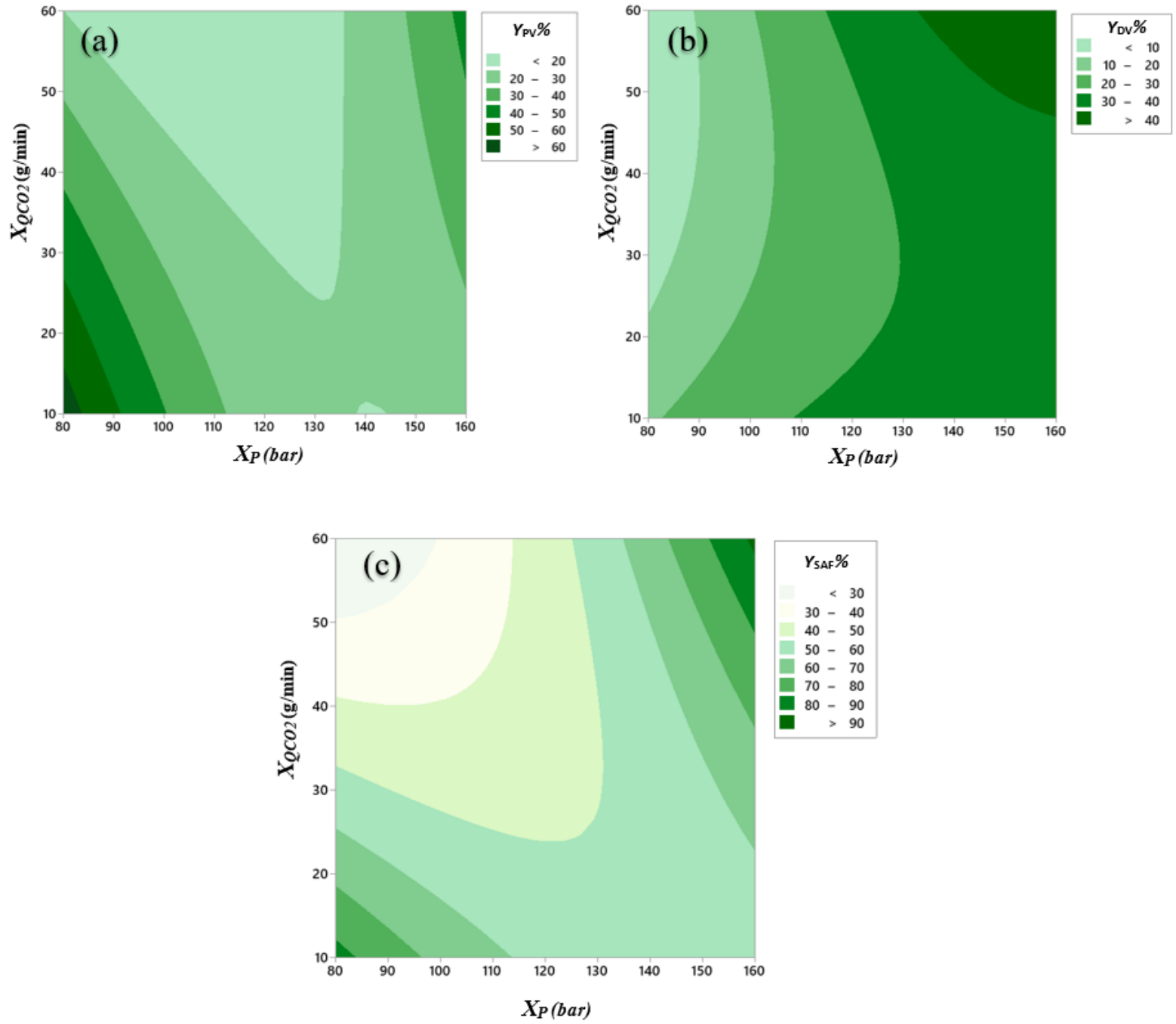

Figure 4. Contour plots of the yields: (a) at PV, $Y_{\mathrm{PV}} \%,(\mathbf{b})$ at DV, $Y_{\mathrm{DV}} \%$, and (c) overall yield, $Y_{\mathrm{SAF}} \%$, as function of pressure, $\mathrm{X}_{\mathrm{P}}$ (bar) and $\mathrm{CO}_{2}$ flow rate, $\mathrm{X}_{\mathrm{QCO}_{2}}(\mathrm{~g} / \mathrm{min})$.

\subsection{Enrichment Ratio Analysis}

In addition to the SAF global yields, ferulic acid (FA), caffeic acid (CAF) and chlorogenic acid (CHA) were monitored for the feed solution fraction (FS), precipitation vessel $(\mathrm{PV})$ and downstream vessel (DV). The enrichment ratios $E_{\mathrm{i} / \mathrm{j}}$ and $E_{\mathrm{ALL} / \mathrm{PV}}$, defined by Equations (6) and (7), are gathered in Table 3 for all experiments performed. No $E_{\mathrm{i} / \mathrm{DV}}$ is included, since the amount of none of the three compounds tracked (FA, CAF, CHA) was higher than the chromatographic detection limit, which indicates that they are mostly found in PV.

Only $E_{\mathrm{CHA} / \mathrm{PV}}, E_{\mathrm{FA} / \mathrm{PV}}$, and $E_{\mathrm{ALL} / \mathrm{PV}}$ were correctly adjusted to Equation (8). The fitting coefficients of this equation are given in Table 4 , where it can be seen that $E_{\mathrm{CHA} / \mathrm{PV}}$ depends on all of the terms except the cross term $\left(\beta_{12}\right)$, and all of them are significant $(p<0.05)$ except for the linear term of the $\mathrm{CO}_{2}$ flow rate $\left(\beta_{2}\right)$. $E_{\mathrm{FA} / \mathrm{PV}}$ and $E_{\mathrm{ALL} / \mathrm{PV}}$ also depend on all terms except for the cross term $\left(\beta_{12}\right)$, but only $\beta_{0}$ and the linear and quadratic pressure terms $\left(\beta_{1}, \beta_{11}\right)$ are significant.

Figure $5 \mathrm{a}-\mathrm{c}$ shows the contour plot corresponding to the surface defined by Equation (8) for the $E_{\mathrm{CHA} / \mathrm{PV}}, E_{\mathrm{FA} / \mathrm{PV}}$, and $E_{\mathrm{ALL} / \mathrm{PV}}$ enrichment ratios. As Figure 5a initially shows, $E_{\mathrm{CHA} / \mathrm{PV}}$ increases as pressure increases and then decreases at higher pressure values. For a fixed pressure, $E_{\mathrm{CHA} / \mathrm{PV}}$ behaves similarly with increasing $\mathrm{CO}_{2}$ flow rate. Then, the maximum is located in a central area, with pressure values between 103 and 150 bar and $\mathrm{CO}_{2}$ flow rates of $12-53 \mathrm{~g} / \mathrm{min} . E_{\mathrm{FA} / \mathrm{PV}}$ and $E_{\mathrm{ALL}}$ have a similar behaviour, as 
can be seen from Figure 5 b,c. The maximum of $E_{\mathrm{FA} / \mathrm{PV}}$ is found for medium-high pressure values (117-147 bar) and intermediate $\mathrm{CO}_{2}$ flow rate values $(14-47 \mathrm{~g} / \mathrm{min})$ within the considered intervals. For the enrichment of the three antioxidants, $E_{\mathrm{ALL} / \mathrm{PV}}$, the maximum zone is found at intermediate values of both pressure and $\mathrm{CO}_{2}$ flow rate (118-142 bar, $18-44 \mathrm{~g} / \mathrm{min})$.
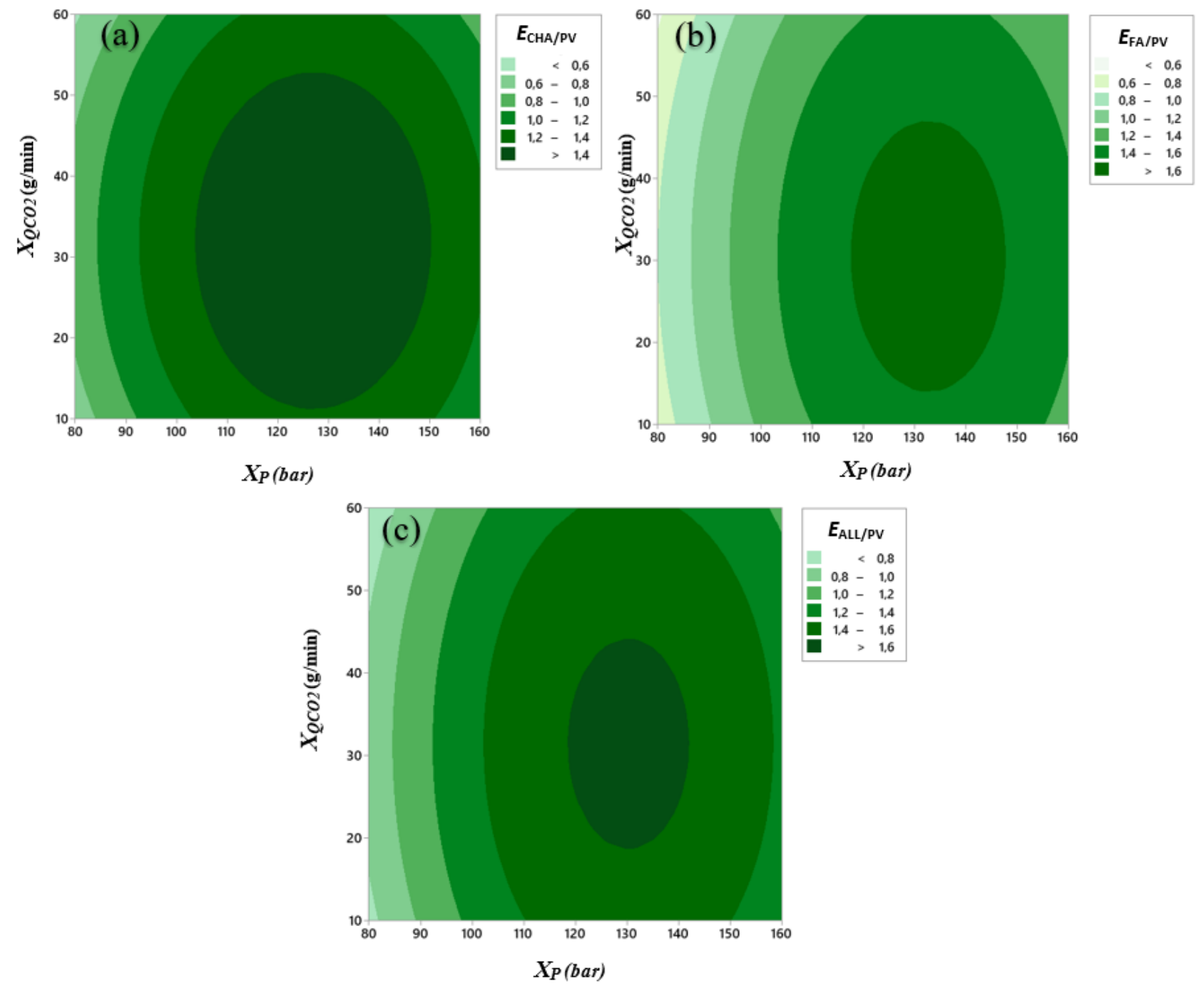

Figure 5. Contour plots of the enrichment ratios: (a) $E_{C H A / P V} ;$ (b) $E_{F A / P V}$, and (c) $E_{A L L / P V}$ as a function of pressure, $\mathrm{X}_{\mathrm{P}}(\mathrm{bar})$, and $\mathrm{CO}_{2}$ flow rate, $\mathrm{X}_{\mathrm{QCO}_{2}}(\mathrm{~g} / \mathrm{min})$.

The fact that all of the analysed compounds, CHA, FA and CAF, are retained in PV makes the SAF technique perfect for obtaining a fraction enriched in these antioxidant compounds. Considering the precautions for experimental inaccuracies, the applied RSM model provides the upper limit of working conditions for achieving a significant enrichment of the compounds of interest. Optimum yield and enrichment values, provided by the applied RSM model, can be obtained working under conditions of $153 \mathrm{bar}$ and $42 \mathrm{~g} / \mathrm{min}$.

In relation to the physical-mathematical treatment of the considered SAF process, it can be indicated that there are close similarities with the well-known supercritical antisolvent precipitation (SAS) processes suitable for the production of fine powders, or even composites including a bioactive substance and a polymer. However, the SAF modelling turns out to be much more complex, because mixtures consisting of a high number of components, such as the natural extracts studied in this work, are considered. Tentatively, most of the developments for the different steps implied in SAS could be adapted to SAF [32]. There are specialized papers about SAS that model both the whole process [67-69] as well as specific 
steps, such as breakup of the feed solution jet in the supercritical $\mathrm{CO}_{2}$ stream [70-72], mass transfer between droplets of organic solution and the compressed antisolvent [73-75], supersaturation and nucleation rate [76-78], growth mechanism [79], or the influence of the variables on precipitation [80]. However, as explained in a previous work [50], detailed modelling of the SAF process is quite a complex task, because of the high number of components in the extracts that usually need to be processed, then becoming rather inextricable from a rigorous theoretical study. In addition, reaction or association processes between the different components can occur. Therefore, and to the best of our knowledge, to date, there are no publications on the detailed theoretical modelling of SAF.

In any case, it seems clear that the different solubilities shown by the components of the mixture to be separated in the supercritical ethanol- $\mathrm{CO}_{2}$ mixture play an essential role in the fractionation process. In fact, it can be mentioned here that a very simple semi-empirical model containing the operating parameters (temperature and pressure) and the Hansen solubility parameters has been proved to be appropriate for describing the selectivity in a GAS-fractionation process closely related to SAF and SAS [81,82].

Related to the system considered in this work, it can be pointed out that the feed solutions present a glutinous character, which may be due to components such as resins or mucilage $[83,84]$ not being completely solubilized. The presence of this solid material could induce a very effective process of heterogeneous nucleation [76]. This is how a practically complete precipitation in PV of the widely supersaturated CAF, CHA and FA occurs.

The optimal conditions for optimum yield and enrichment values, indicated above (153 bar, $42 \mathrm{~g} / \mathrm{min}$ ), are located between the extreme values of the ranges studied. This could be explained by the opposing effects that take place both for the increase in $\mathrm{CO}_{2}$ flow rate and pressure. An increase of $\mathrm{CO}_{2}$ flow rate implies a higher dragging effect, but also favours better mixing and nucleation. For its part, an increase in pressure would increase solubility, but favours nucleation of solutes.

\subsection{Results of the Skin Model}

The skin model applied was a fully hydrated skin model, and all the calculations for resistances, possible pathways and overall permeability values were performed using the COSMOtherm software package. The predicted values for Equations (9)-(11) for individual compounds are gathered in Table 5 .

The compartment with the largest resistance for CAF and FA is the stratum corneum $\left(\log R_{\mathrm{SC}}=-5.61\right.$ and -5.51 respectively), while for CHA, the largest resistance is the stratum spinosum $\left(\log R_{\mathrm{SS}}=-7.06\right)$. This means that while for CAF and FA the stratum corneum is the main barrier in the penetration process, for CHA it manages to penetrate up to the stratum spinosum. Regarding the penetration pathway, both CAF and FA prefer the trans-corneocyte route $\left(R_{\mathrm{SC}}\right.$, inter $>>R_{\mathrm{SC}}$, trans $)$, while $\mathrm{CHA}$ prefers the transcellular

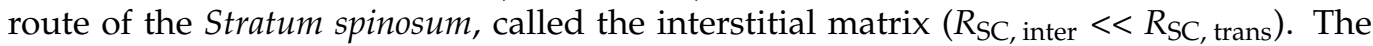
overall resistances, $R_{\text {skin }}$, including the shunt pathway, are $R_{\text {skin }}=R_{\text {skin }}=7.74 \times 10^{7}$, $1.86 \times 10^{9}$ and $3.74 \times 10^{7}$ for CAF, CHA and FA, respectively. Translating them using Equation (9), the permeability values for each compound were $\log K_{\mathrm{p}}=-5.89$ for CAF, $\log K_{\mathrm{p}}=-7.27$ for CHA and $\log K_{\mathrm{p}}=-5.57$ for FA. These values are corrected by a constant offset $\left(\Delta \log K_{\mathrm{p}}=-1.12 \mathrm{~cm} / \mathrm{s}\right)$ [46], and the final permeability values are $\log K_{\mathrm{p}}=-7.01$, -8.39 and -6.69 for CAF, CHA and FA, respectively. Table 5 also shows the average calculated permeability values of CAF and FA in skin by Zhang et al. [85], and experimental permeability values from Caco-2 cells for CAF, CHA and FA [86,87], as well as the deviation of our corrected values $\log K_{\mathrm{p}}$. It can be seen that our $\log K_{\mathrm{p}}$ corrected values fit better to $\log K_{\mathrm{p}}$ (calc) of skin by Zhang et al. (deviation $=0.16$ and -0.46 for CAF and FA) than to the values of $\log K_{\mathrm{p}}$ (exp) of Caco-2 cells (deviation $=1.17,2.79$ and 1.71 for $\mathrm{CAF}, \mathrm{CHA}$ and FA respectively). This may be due to the fact that Caco-2 cell lines are used as a model of intestinal absorption and the estimation of oral bioavailability [88], and therefore, their permeability differs from the permeability of the skin. For a compound to be considered toxic, it must reach a certain layer of the skin. Stratum corneum, consisting 
mainly of dead cells, is considered a safe layer in which toxicity or irritation does not occur [89]. This makes both CAF and FA safe for cosmetic use. CHA, on the other hand, reaches a deeper layer of the epidermis, but does not reach the dermis, and furthermore, its permeability coefficient is lower than the desquamation rate coefficient $\left(\log K_{D}=-9\right)$ [90], which also makes it safe for cosmetic use. This desquamation rate coefficient indicates that even if a compound penetrates beyond the stratum corneum, the skin regenerates and prevents the compound from penetrating deeper in the epidermis [89].

Table 5. Detailed model parameters of resistances and and $K_{\mathrm{p}}$ (predicted, calculated, experimental and their deviations) for $\mathrm{CAF}, \mathrm{CHA}$ and FA for each compartment and their permeation path.

\begin{tabular}{|c|c|c|c|}
\hline Parameter & Caffeic Acid & Chlorogenic Acid & Ferulic Acid \\
\hline Vehicle & water & water & water \\
\hline Skin membrane & epidermis & epidermis & epidermis \\
\hline Rate limiting step & $\begin{array}{c}\text { SC via polar trans-corneocyte } \\
\text { pathway }\end{array}$ & SS via interstitial space & $\begin{array}{c}\text { SC via polar trans-corneocyte } \\
\text { pathway }\end{array}$ \\
\hline $\log K_{\text {vehicle:water }}$ & 0.00 & 0.00 & 0.00 \\
\hline$R_{\mathrm{SC} \text {,inter }}(\mathrm{s} / \mathrm{m})$ & $2.15 \times 10^{12}$ & $8.20 \times 10^{16}$ & $2.55 \times 10^{11}$ \\
\hline$R_{\mathrm{SC}, \text { trans }}(\mathrm{s} / \mathrm{m})$ & $4.07 \times 10^{7}$ & $1.76 \times 10^{8}$ & $3.23 \mathrm{E} \times 10^{7}$ \\
\hline$R_{\mathrm{SC}}(\mathrm{s} / \mathrm{m})$ & $4.07 \times 10^{7}$ & $1.76 \times 10^{8}$ & $3.23 \mathrm{E} \times 10^{7}$ \\
\hline $\log R_{\mathrm{SC}}(\mathrm{cm} / \mathrm{s})$ & -5.09 & -6.71 & -4.21 \\
\hline$R_{\mathrm{SG}, \text { inter }}(\mathrm{s} / \mathrm{m})$ & $1.26 \times 10^{8}$ & $5.14 \times 10^{8}$ & $1.23 \times 10^{8}$ \\
\hline$R_{\mathrm{SG}, \text { trans }}(\mathrm{s} / \mathrm{m})$ & $1.34 \times 10^{7}$ & $5.13 \times 10^{11}$ & $1.63 \times 10^{6}$ \\
\hline$R_{\mathrm{SG}}(\mathrm{s} / \mathrm{m})$ & $1.22 \times 10^{7}$ & $5.13 \mathrm{E} \times 10^{8}$ & $1.61 \times 10^{6}$ \\
\hline $\log R_{\mathrm{SG}}(\mathrm{cm} / \mathrm{s})$ & -5.32 & -7.06 & -4.46 \\
\hline$R_{\mathrm{SS}, \text { inter }}(\mathrm{s} / \mathrm{m})$ & $2.86 \times 10^{8}$ & $1.17 \times 10^{9}$ & $2.80 \times 10^{8}$ \\
\hline$R_{\mathrm{SS}, \text { trans }}(\mathrm{s} / \mathrm{m})$ & $2.26 \times 10^{7}$ & $8.54 \times 10^{11}$ & $2.91 \times 10^{6}$ \\
\hline$R_{\mathrm{SS}}(\mathrm{s} / \mathrm{m})$ & $2.09 \times 10^{7}$ & $1.16 \times 10^{9}$ & $2.88 \times 10^{6}$ \\
\hline $\log R_{\mathrm{SS}}(\mathrm{cm} / \mathrm{s})$ & -4.57 & -5.91 & -3.80 \\
\hline$R_{\mathrm{SB}, \text { inter }}(\mathrm{s} / \mathrm{m})$ & $1.98 \times 10^{7}$ & $8.07 \times 10^{7}$ & $1.94 \times 10^{7}$ \\
\hline$R_{\mathrm{SB}, \text { trans }}(\mathrm{s} / \mathrm{m})$ & $4.58 \mathrm{E} \times 10^{6}$ & $1.71 \times 10^{11}$ & $6.50 \times 10^{5}$ \\
\hline$R_{\mathrm{SB}}(\mathrm{s} / \mathrm{m})$ & $3.72 \times 10^{6}$ & $8.06 \times 10^{7}$ & $6.29 \times 10^{5}$ \\
\hline $\log R_{\mathrm{SB}}(\mathrm{cm} / \mathrm{s})$ & -5.89 & -7.27 & -5.57 \\
\hline$R_{\text {cells }}(\mathrm{s} / \mathrm{m})$ & $7.75 \times 10^{7}$ & $1.93 \times 10^{9}$ & $3.74 \mathrm{E} \times 10^{7}$ \\
\hline$R_{\text {shunt }}(\mathrm{s} / \mathrm{m})$ & $5.00 \times 10^{10}$ & $5.00 \times 10^{10}$ & $5.00 \times 10^{10}$ \\
\hline$R_{\text {skin }}(\mathrm{s} / \mathrm{m})$ & $7.74 \times 10^{7}$ & $1.86 \times 10^{9}$ & $3.74 \mathrm{E} \times 10^{7}$ \\
\hline $\log K_{\mathrm{p}}($ pred.) $(\mathrm{cm} / \mathrm{s})$ & -5.89 & -7.27 & -5.57 \\
\hline $\log K_{\mathrm{p}}$ (pred.) + cte offset $(\mathrm{cm} / \mathrm{s})$ & -7.01 & -8.39 & -6.69 \\
\hline $\log K_{\mathrm{p}}$ (calc.) epidermis (cm/s) & -6.85 & - & -7.15 \\
\hline Deviation & 0.16 & - & 0.46 \\
\hline $\log K_{\mathrm{p}}(\exp .) \mathrm{Caco}-2(\mathrm{~cm} / \mathrm{s})$ & -5.84 & -5.60 & -4.98 \\
\hline Deviation & 1.17 & 2.79 & 1.71 \\
\hline
\end{tabular}

\section{Conclusions}

The combination of two advanced separation techniques applied to Calendula officinalis flowers was successfully used to obtain extracts of interest in cosmetics. The initial supercritical extraction with $\mathrm{CO}_{2}$ (SCE) carried out, the yield of which was $8.3 \%$ and the subsequent maceration in ethanol applied, the yield of which was $8 \%$, showed results similar to those obtained in works by other authors. Subsequently, the ability of the supercritical antisolvent fractionation (SAF) technique to fractionate the ethanolic extract to obtain an enriched fraction in the tracked compounds (CHA, FA, CAF) was satisfactorily evaluated through a Response Surface Methodology (RSM) based on Central Composite Design (CCD). Chlorogenic acid, ferulic acid and caffeic acid were obtained almost exclusively in the precipitated fraction, thus obtaining a fraction enriched in antioxidant compounds of great interest in the cosmetic industry and even with possible applications in the pharmaceutical or food industry. The CCD design also made it possible to deduce 
the pressure and $\mathrm{CO}_{2}$ flow rate conditions to obtain optimal yields and enrichment values were 153 bar and $42 \mathrm{~g} / \mathrm{min}$ (composite desirability $=0.673$ ).

Regarding the skin permeability model used, it was possible to evaluate the computational permeability of CAF, CHA and FA. In all cases, none of the compounds pass through the epidermis completely, which means that they are safe compounds for topical use on the skin. The final permeability values predicted by the model were $\log K_{p}=-7.01,-8.39$ and -6.69 for CAF, CHA and FA, respectively and were compared with experimental values for both abdominal skin cells and Caco-2 intestinal cells, concluding that the skin model is a good model for predicting permeabilities and behaviours of compounds in the epidermis.

Although the SCE was carried out to favour obtaining the antioxidant phase, the extracts obtained through this technique are of great value due to their composition, and they are widely used in the cosmetic industry. In fact, a cosmetic formulation has been prepared containing extracts of $C$. officinalis, obtained under the conditions used in this work, that has been approved by the French agency ASNM (L'Agence nationale de sécurité du médicament et des produits de santé), and it is now being tested on human volunteers at MEDES (Institut de Médicine et de Physiologie Spatiales, Toulouse, France). All this makes these two advanced separation techniques (SCE and SAF), together with the experimental design and the skin permeability model used, powerful tools for obtaining, concentrating and evaluating compounds of interest to the cosmetic industry.

Supplementary Materials: The following are available online at https:/ /www.mdpi.com/article/10 .3390/antiox11010096/s1, Info S1: Cartesian Coordinates for Optimized Geometries in Gas Phase at bvp86.

Author Contributions: Conceptualization, Resources, Supervision, Project administration and Funding acquisition, A.M.M. and J.S.U.; Methodology and software, R.M. and A.M.M.; Validation, A.M.M.; Formal analysis, R.M.; Investigation, R.M. and A.M.M.; Data curation, R.M., E.L., M.R.P.-O. and A.M.M.; Writing—original draft preparation, R.M.; Writing—review and editing, R.M., E.L., M.R.P.O., J.S.U. and A.M.M.; Visualization, E.L., M.R.P.-O. and A.M.M. All authors have read and agreed to the published version of the manuscript.

Funding: The authors thank to EFA188/16/SPAGYRIA (Este proyecto está cofinanciado por el Fondo Europeo de Desarrollo Regional (FEDER)) and Gobierno de Aragón: Departamento de Ciencia, Universidad y Sociedad del Conocimiento: Group E39_20R.

Institutional Review Board Statement: Not applicable.

Informed Consent Statement: Not applicable.

Data Availability Statement: Data is contained within the article and the Supplementary Materials.

Acknowledgments: The authors acknowledge generous allocations of computer time in the Hermes Cluster from the Aragon Institute for Engineering Research (I3A)—University of Zaragoza. The authors thank T. V. for her technical assistance.

Conflicts of Interest: The authors declare no conflict of interest.

\section{References}

1. Arora, D.; Rani, A.; Sharma, A. A Review on Phytochemistry and Ethnopharmacological Aspects of Genus Calendula. Pharmacogn. Rev. 2013, 7, 179-187. [CrossRef]

2. $\quad$ Barnes, J.; Anderson, L.A.; Phillipson, J.D. Herbal Medicines, 3rd ed.; Pharmaceutical Press: London, UK; Grayslake, IL, USA, 2007; ISBN 978-0-85369-623-0.

3. European Scientific Cooperative on Phytotherapy. ESCOP Monographs, The Scientific Foundation for Herbal Medicinal Products. Online Series. Calendulae Flos (Calendula Flower); ESCOP: Exeter, UK, 2019; ISBN 978-1-901964-61-5.

4. European Medicines Agency Overview of Comments Recieved on Community Herbal Monograph on Calendula officinalis L., Flos. Available online: https://www.ema.europa.eu/en/documents/herbal-monograph/final-european-union-herbal-monographcalendula-officinalis-1-flos-revision-1_en.pdf (accessed on 26 July 2021).

5. World Health Organization Geneva. WHO Monographs on Selected Medicinal Plants; WHO Graphics: Malta, 2002; Volume 2, ISBN 92-4-154537-2. 
6. Mishra, A.; Mishra, A.; Chattopadhyay, P. Calendula officinalis: An Important Herb with Valuable Therapeutic Dimensions-An Overview. J. Global Pharma Technol. 2010, 10, 2. [CrossRef]

7. European Comission CosIng-Cosmetics—Calendula officinalis Callus Extract. Available online: https://ec.europa.eu/growth/ tools-databases/cosing/index.cfm?fuseaction=search.details_v2\&id=95567 (accessed on 21 July 2021).

8. European Commission CosIng-Cosmetics-Calendula officinalis Flower Oil. Available online: https:/ / ec.europa.eu/growth/ tools-databases / cosing/index.cfm?fuseaction=search.details_v2\&id=74930 (accessed on 21 July 2021).

9. European Commission CosIng-Cosmetics-Calendula officinalis Flower Water. Available online: https://ec.europa.eu/growth/ tools-databases/cosing/index.cfm?fuseaction=search.details_v2\&id=83485 (accessed on 21 July 2021).

10. Mishra, A.; Chattopadhyay, P. Assessment of In Vitro Sun Protection Factor of Calendula officinalis L. (Asteraceae) Essential Oil Formulation. J. Young Pharm. JYP 2012, 4, 17-21. [CrossRef] [PubMed]

11. Efstratiou, E.; Hussain, A.I.; Nigam, P.S.; Moore, J.E.; Ayub, M.A.; Rao, J.R. Antimicrobial Activity of Calendula Officinalis Petal Extracts against Fungi, as Well as Gram-Negative and Gram-Positive Clinical Pathogens. Complement. Ther. Clin. Pract. 2012, 18, 173-176. [CrossRef] [PubMed]

12. Klouchek-Popova, E.; Popov, A.; Pavlova, N.; Krŭsteva, S. Influence of the Physiological Regeneration and Epithelialization Using Fractions Isolated from Calendula Officinalis. Acta Physiol. Pharmacol. Bulg. 1982, 8, 63-67.

13. Duran, V.; Matic, M.; Jovanovć, M.; Mimica, N.; Gajinov, Z.; Poljacki, M.; Boza, P. Results of the Clinical Examination of an Ointment with Marigold (Calendula officinalis) Extract in the Treatment of Venous Leg Ulcers. Int. J. Tissue React 2005, 27, 101-106. [PubMed]

14. Fonseca, Y.M.; Catini, C.D.; Vicentini, F.T.M.C.; Cardoso, J.C.; Cavalcanti De Albuquerque Junior, R.L.; Vieira Fonseca, M.J. Efficacy of Marigold Extract-Loaded Formulations Against UV-Induced Oxidative Stress. J. Pharm. Sci. 2011, 100, $2182-2193$. [CrossRef]

15. ZitterlEglseer, K.; Sosa, S.; Jurenitsch, J.; SchubertZsilavecz, M.; DellaLoggia, R.; Tubaro, A.; Bertoldi, M.; Franz, C. AntiOedematous Activities of the Main Triterpendiol Esters of Marigold (Calendula officinalis L.). J. Ethnopharmacol. 1997, 57, 139-144. [CrossRef]

16. Loggia, R.D.; Tubaro, A.; Sosa, S.; Becker, H.; Saar, S.; Isaac, O. The Role of Triterpenoids in the Topical Anti-Inflammatory Activity of Calendula officinalis Flowers. Planta Med. 1994, 60, 516-520. [CrossRef]

17. Ukiya, M.; Akihisa, T.; Yasukawa, K.; Tokuda, H.; Suzuki, T.; Kimura, Y. Anti-Inflammatory, Anti-Tumor-Promoting, and Cytotoxic Activities of Constituents of Marigold (Calendula Officinalis) Flowers. J. Nat. Prod. 2006, 69, 1692-1696. [CrossRef]

18. Jimenez-Medina, E.; Garcia-Lora, A.; Paco, L.; Algarra, I.; Collado, A.; Garrido, F. A New Extract of the Plant Calendula officinalis Produces a Dual In Vitro Effect: Cytotoxic Anti-Tumor Activity and Lymphocyte Activation. BMC Cancer 2006, 6, 119. [CrossRef]

19. Shivasharan, B.D.; Nagakannan, P.; Thippeswamy, B.S.; Veerapur, V.P.; Bansal, P.; Unnikrishnan, M.K. Protective Effect of Calendula officinalis Linn. Flowers against 3-Nitropropionic Acid Induced Experimental Huntington's Disease in Rats. Drug Chem. Toxicol. 2013, 36, 466-473. [CrossRef]

20. Ray, D.; Mukherjee, S.; Falchi, M.; Bertelli, A.; Braga, P.C.; Das, D.K. Amelioration of Myocardial Ischemic Reperfusion Injury with Calendula officinalis. Curr. Pharm. Biotechnol. 2010, 11, 849-854. [CrossRef]

21. Urbaniak, A.; Kujawski, J.; Czaja, K.; Szelag, M. Antioxidant Properties of Several Caffeic Acid Derivatives: A Theoretical Study. C. R. Chim. 2017, 20, 1072-1082. [CrossRef]

22. Zdunska, K.; Dana, A.; Kolodziejczak, A.; Rotsztejn, H. Antioxidant Properties of Ferulic Acid and Its Possible Application. Ski. Pharmacol. Physiol. 2018, 31, 332-336. [CrossRef]

23. Agunloye, O.M.; Oboh, G.; Ademiluyi, A.O.; Ademosun, A.O.; Akindahunsi, A.A.; Oyagbemi, A.A.; Omobowale, T.O.; Ajibade, T.O.; Adedapo, A.A. Cardio-Protective and Antioxidant Properties of Caffeic Acid and Chlorogenic Acid: Mechanistic Role of Angiotensin Converting Enzyme, Cholinesterase and Arginase Activities in Cyclosporine Induced Hypertensive Rats. Biomed. Pharmacother. 2019, 109, 450-458. [CrossRef] [PubMed]

24. Kim, S.R.; Jung, Y.R.; An, H.J.; Kim, D.H.; Jang, E.J.; Choi, Y.J.; Moon, K.M.; Park, M.H.; Park, C.H.; Chung, K.W.; et al. AntiWrinkle and Anti-Inflammatory Effects of Active Garlic Components and the Inhibition of MMPs via NF-KB Signaling. PLoS ONE 2013, 8, e73877. [CrossRef]

25. Dias Alves, G.d.A.; de Souza, R.O.; Ghislain Rogez, H.L.; Masaki, H.; Vieira Fonseca, M.J. Cecropia Obtusa Extract and Chlorogenic Acid Exhibit Anti Aging Effect in Human Fibroblasts and Keratinocytes Cells Exposed to UV Radiation. PLoS ONE 2019, 14, e0216501. [CrossRef]

26. Girsang, E.; Ginting, C.N.; Lister, I.N.E.; Gunawan, K.Y.; Widowati, W. Anti-Inflammatory and Antiaging Properties of Chlorogenic Acid on UV-Induced Fibroblast Cell. PeerJ 2021, 9, e11419. [CrossRef]

27. Kaczmarek, B.; Lewandowska, K.; Sionkowska, A. Modification of Collagen Properties with Ferulic Acid. Materials 2020, 13 , 3419 [CrossRef] [PubMed]

28. Saija, A.; Tomaino, A.; Lo Cascio, R.; Trombetta, D.; Proteggente, A.; De Pasquale, A.; Uccella, N.; Bonina, F. Ferulic and Caffeic Acids as Potential Protective Agents against Photooxidative Skin Damage. J. Sci. Food Agric. 1999, 79, 476-480. [CrossRef]

29. Zhu, H.; Zhao, H.; Zhang, Z.; Wang, W.; Yao, S. Laser Flash Photolysis Study on Antioxidant Properties of Hydroxycinnamic Acid Derivatives. Radiat. Environ. Biophys. 2006, 45, 73-77. [CrossRef]

30. Staniforth, V.; Chiu, L.-T.; Yang, N.-S. Caffeic Acid Suppresses UVB Radiation-Induced Expression of Interleukin-10 and Activation of Mitogen-Activated Protein Kinases in Mouse. Carcinogenesis 2006, 27, 1803-1811. [CrossRef] 
31. Taofiq, O.; Gonzalez-Paramas, A.M.; Barreiro, M.F.; Ferreira, I.C.F.R. Hydroxycinnamic Acids and Their Derivatives: Cosmeceutical Significance, Challenges and Future Perspectives, a Review. Molecules 2017, 22, 281. [CrossRef]

32. Reverchon, E.; De Marco, I. Supercritical Fluid Extraction and Fractionation of Natural Matter. J. Supercrit. Fluids 2006, 38, 146-166. [CrossRef]

33. de Melo, M.M.R.; Silvestre, A.J.D.; Silva, C.M. Supercritical Fluid Extraction of Vegetable Matrices: Applications, Trends and Future Perspectives of a Convincing Green Technology. J. Supercrit. Fluids 2014, 92, 115-176. [CrossRef]

34. Burt, S. Essential Oils: Their Antibacterial Properties and Potential Applications in Foods-A Review. Int. J. Food Microbiol. 2004, 94, 223-253. [CrossRef]

35. Herrero, M.; Cifuentes, A.; Ibanez, E. Sub- and Supercritical Fluid Extraction of Functional Ingredients from Different Natural Sources: Plants, Food-by-Products, Algae and Microalgae. A Review. Food Chem. 2006, 98, 136-148. [CrossRef]

36. Giacometti, J.; Bursać Kovačević, D.; Putnik, P.; Gabrić, D.; Bilušić, T.; Krešić, G.; Stulić, V.; Barba, F.J.; Chemat, F.; Barbosa-Cánovas, G.; et al. Extraction of Bioactive Compounds and Essential Oils from Mediterranean Herbs by Conventional and Green Innovative Techniques: A Review. Food Res. Int. 2018, 113, 245-262. [CrossRef] [PubMed]

37. Hamburger, M.; Adler, S.; Baumann, D.; Forg, A.; Weinreich, B. Preparative Purification of the Major Anti-Inflammatory Triterpenoid Esters from Marigold (Calendula officinalis). Fitoterapia 2003, 74, 328-338. [CrossRef]

38. Danielski, L.; Campos, L.M.A.S.; Bresciani, L.F.V.; Hense, H.; Yunes, R.A.; Ferreira, S.R.S. Marigold (Calendula officinalis L.) Oleoresin: Solubility in SC-CO 2 and Composition Profile. Chem. Eng. Process. 2007, 46, 99-106. [CrossRef]

39. Petrovic, L.; Lepojevic, Z.; Sovilj, V.; Adamovic, D.; Tesevic, V. An Investigation of $\mathrm{CO}_{2}$ Extraction of Marigold (Calendula officinalis L.). J. Serb. Chem. Soc. 2007, 72, 407-413. [CrossRef]

40. Petrovic, L.; Lepojevic, Z.; Sovilj, V.; Adamovic, D.; Tesevic, V. Composition of Essential Oil Obtained from Tubular, Head and Ligulate Flowers of Calendula officinalis L. by Steam Distillation of Plant Material and $\mathrm{CO}_{2}$ Extracts. J. Essent. Oil Res. 2010, 22, 143-146. [CrossRef]

41. Gimenez-Rota, C.; Langa, E.; Urieta, J.S.; Hernaiz, M.J.; Mainar, A.M. Supercritical Antisolvent Fractionation of Antioxidant Compounds from Lavandula Luisieri (Rozeira) Riv.-Mart. J. Supercrit. Fluids 2020, 161, 104821. [CrossRef]

42. Martin, L.; Gonzalez-Coloma, A.; Adami, R.; Scognamiglio, M.; Reverchon, E.; Della Porta, G.; Urieta, J.S.; Mainar, A.M. Supercritical Antisolvent Fractionation of Ryanodol from Persea Indica. J. Supercrit. Fluids 2011, 60, 16-20. [CrossRef]

43. Sanchez-Camargo, A.P.; Mendiola, J.A.; Valdes, A.; Castro-Puyana, M.; Garcia-Canas, V.; Cifuentes, A.; Herrero, M.; Ibanez, E. Supercritical Antisolvent Fractionation of Rosemary Extracts Obtained by Pressurized Liquid Extraction to Enhance Their Antiproliferative Activity. J. Supercrit. Fluids 2016, 107, 581-589. [CrossRef]

44. Gimenez-Rota, C.; Loran, S.; Mainar, A.M.; Hernaiz, M.J.; Rota, C. Supercritical Carbon Dioxide Antisolvent Fractionation for the Sustainable Concentration of Lavandula luisieri (Rozeira) Riv.- Mart Antimicrobial and Antioxidant Compounds and Comparison with Its Conventional Extracts. Plants 2019, 8, 455. [CrossRef]

45. Langa, E.; Pardo, J.I.; Gimenez-Rota, C.; Gonzalez-Coloma, A.; Hernaiz, M.J.; Mainar, A.M. Supercritical Anti-Solvent Fractionation of Artemisia Absinthium L. Conventional Extracts: Tracking Artemetin and Casticin. J. Supercrit. Fluids 2019, 151, 15-23. [CrossRef]

46. Schwöbel, J.A.H.; Klamt, A. Mechanistic Skin Penetration Model by the COSMOperm Method: Routes of Permeation, Vehicle Effects and Skin Variations in the Healthy and Compromised Skin. Comput. Toxicol. 2019, 11, 50-64. [CrossRef]

47. Tsakovska, I.; Pajeva, I.; Al Sharif, M.; Alov, P.; Fioravanzo, E.; Kovarich, S.; Worth, A.P.; Richarz, A.-N.; Yang, C.; MostragSzlichtyng, A.; et al. Quantitative Structure-Skin Permeability Relationships. Toxicology 2017, 387, 27-42. [CrossRef]

48. Ates, G.; Steinmetz, F.P.; Doktorova, T.Y.; Madden, J.C.; Rogiers, V. Linking Existing In Vitro Dermal Absorption Data to Physicochemical Properties: Contribution to the Design of a Weight-of-Evidence Approach for the Safety Evaluation of Cosmetic Ingredients with Low Dermal Bioavailability. Regul. Toxicol. Pharmacol. 2016, 76, 74-78. [CrossRef]

49. Williams, F.M.; Rothe, H.; Barrett, G.; Chiodini, A.; Whyte, J.; Cronin, M.T.D.; Monteiro-Riviere, N.A.; Plautz, J.; Roper, C.; Westerhout, J.; et al. Assessing the Safety of Cosmetic Chemicals: Consideration of a Flux Decision Tree to Predict Dermally Delivered Systemic Dose for Comparison with Oral TTC (Threshold of Toxicological Concern). Regul. Toxicol. Pharmacol. 2016, 76, 174-186. [CrossRef] [PubMed]

50. Wilcox, R.A.; Deyoe, C.W.; Pfost, H.B. A Method for Determining and Expressing the Size of Feed Particles by Sieving. Poult. Sci. 1970, 49, 9-13. [CrossRef]

51. Mur, R.; Pardo, J.I.; Pino-Otín, M.R.; Urieta, J.S.; Mainar, A.M. Supercritical Antisolvent Fractionation of Antioxidant Compounds from Salvia Officinalis. Int. J. Mol. Sci. 2021, 22, 9351. [CrossRef]

52. Marqués, J.L.; Porta, G.D.; Reverchon, E.; Renuncio, J.A.R.; Mainar, A.M. Supercritical Antisolvent Extraction of Antioxidants from Grape Seeds after Vinification. J. Supercrit. Fluids 2013, 82, 238-243. [CrossRef]

53. Klamt, A. Conductor-Like Screening Model for Real Solvents-A New Approach to the Quantitative Calculation of Solvation Phenomena. J. Phys. Chem. 1995, 99, 2224-2235. [CrossRef]

54. Klamt, A. COSMO-RS: From Quantum Chemistry to Fluid Phase Thermodynamics. In Proceedings of the 28th European Symposium on Computer Aided Process Engineering, Graz, Sunday, 10-13 June 2018; Friedl, A., Klemes, J.J., Radl, S., Varbanov, P.S., Wallek, T., Eds.; Elsevier Science Bv: Amsterdam, The Netherlands, 2018; Volume 43, p. 9, ISBN 978-0-444-64235-6.

55. Buggert, M.; Cadena, C.; Mokrushina, L.; Smirnova, I.; Maginn, E.J.; Arlt, W. COSMO-RS Calculations of Partition Coefficients: Different Tools for Conformational Search. Chem. Eng. Technol. 2009, 32, 977-986. [CrossRef] 
56. Klamt, A.; Huniar, U.; Spycher, S.; Keldenich, J. COSMOmic: A Mechanistic Approach to the Calculation of Membrane-Water Partition Coefficients and Internal Distributions within Membranes and Micelles. J. Phys. Chem. B 2008, 112, 12148-12157. [CrossRef] [PubMed]

57. Jakobtorweihen, S.; Zuniga, A.C.; Ingram, T.; Gerlach, T.; Keil, F.J.; Smirnova, I. Predicting Solute Partitioning in Lipid Bilayers: Free Energies and Partition Coefficients from Molecular Dynamics Simulations and COSMOmic. J. Chem. Phys. 2014, 141, 045102. [CrossRef]

58. Droge, S.T.J.; Hermens, J.L.M.; Gutsell, S.; Rabone, J.; Hodges, G. Predicting the Phospholipophilicity of Monoprotic Positively Charged Amines. Environ. Sci.-Process. Impacts 2017, 19, 307-323. [CrossRef]

59. Yordanova, D.; Ritter, E.; Gerlach, T.; Jensen, J.H.; Smirnova, I.; Jakobtorweihen, S. Solute Partitioning in Micelles: Combining Molecular Dynamics Simulations, COSMOmic, and Experiments. J. Phys. Chem. B 2017, 121, 5794-5809. [CrossRef]

60. Bittermann, K.; Linden, L.; Goss, K.-U. Screening Tools for the Bioconcentration Potential of Monovalent Organic Ions in Fish Environ. Sci.-Process. Impacts 2018, 20, 845-853. [CrossRef]

61. Klamt, A.; Schwoebel, J.; Huniar, U.; Koch, L.; Terzi, S.; Gaudin, T. COSMOplex: Self-Consistent Simulation of Self-Organizing Inhomogeneous Systems Based on COSMO-RS. Phys. Chem. Chem. Phys. 2019, 21, 9225-9238. [CrossRef]

62. Naegel, A.; Heisig, M.; Wittum, G. Detailed Modeling of Skin Penetration-An Overview. Adv. Drug Deliv. Rev. 2013, 65, 191-207. [CrossRef] [PubMed]

63. Baumann, D.; Adler, S.; Gruner, S.; Otto, F.; Weinreich, B.; Hamburger, M. Supercritical Carbon Dioxide Extraction of Marigold at High Pressures: Comparison of Analytical and Pilot-Scale Extraction. Phytochem. Anal. 2004, 15, 226-230. [CrossRef]

64. Lopez-Padilla, A.; Ruiz-Rodriguez, A.; Reglero, G.; Fornari, T. Supercritical Carbon Dioxide Extraction of Calendula Officinalis: Kinetic Modeling and Scaling up Study. J. Supercrit. Fluids 2017, 130, 292-300. [CrossRef]

65. Hamzawy, M.A.; El-Denshary, E.S.M.; Hassan, N.S.; Mannaa, F.A.; Abdel-Wahhab, M.A. Dietary Supplementation of Calendula Officinalis Counteracts the Oxidative Stress and Liver Damage Resulted from Aflatoxin. ISRN Nutr. 2013, 2013, e538427. [CrossRef] [PubMed]

66. Quintana, S.E.; Villanueva-Bermejo, D.; Reglero, G.; Garcia-Risco, M.R.; Fornari, T. Supercritical Antisolvent Particle Precipitation and Fractionation of Rosemary (Rosmarinus officinalis L.) Extracts. J. $\mathrm{CO}_{2}$ Util. 2019, 34, 479-489. [CrossRef]

67. Martin, A.; Gutierrez, L.; Mattea, F.; Cocero, M.J. Precipitation of Mandelic Acid with a Supercritical Antisolvent Process: Experimental and Theoretical Analysis, Optimization, and Scaleup. Ind. Eng. Chem. Res. 2007, 46, 1552-1562. [CrossRef]

68. Huang, D.; Zhu, Z.; Wang, Q.; Qin, B.; Dai, L.; Jiang, F.; Liu, W.; Qian, H. Prediction Model, Experimental Optimization, and Verification for Yield of High-Pressure Crystallization: A Case Study of Citric Acid. Sep. Sci. Technol. 2020, 55, 135-143. [CrossRef]

69. Reverchon, E.; Caputo, G.; De Marco, I. Role of Phase Behavior and Atomization in the Supercritical Antisolvent Precipitation. Ind. Eng. Chem. Res. 2003, 42, 6406-6414. [CrossRef]

70. Cardoso, M.A.T.; Cabral, J.M.S.; Palavra, A.M.F.; Geraldes, V. CFD Analysis of Supercritical Antisolvent (SAS) Micronization of Minocycline Hydrochloride. J. Supercrit. Fluids 2008, 47, 247-258. [CrossRef]

71. Sikroria, T.; Kushari, A.; Syed, S.; Lovett, J.A. Experimental Investigation of Liquid Jet Breakup in a Cross Flow of a Swirling Air Stream. J. Eng. Gas Turbines Power-Trans. ASME 2014, 136, 061501. [CrossRef]

72. Rantakyla, M.; Jantti, M.; Aaltonen, O.; Hurme, M. The Effect of Initial Drop Size on Particle Size in the Supercritical Antisolvent Precipitation (SAS) Technique. J. Supercrit. Fluids 2002, 24, 251-263. [CrossRef]

73. Werling, J.O.; Debenedetti, P.G. Numerical Modeling of Mass Transfer in the Supercritical Antisolvent Process. J. Supercrit. Fluids 1999, 16, 167-181. [CrossRef]

74. Werling, J.O.; Debenedetti, P.G. Numerical Modeling of Mass Transfer in the Supercritical Antisolvent Process: Miscible Conditions J. Supercrit. Fluids 2000, 18, 11-24. [CrossRef]

75. Mukhopadhyay, M.; Dalvi, S.V. Mass and Heat Transfer Analysis of SAS: Effects of Thermodynamic States and Flow Rates on Droplet Size. J. Supercrit. Fluids 2004, 30, 333-348. [CrossRef]

76. Baldyga, J. Mixing and Fluid Dynamics Effects in Particle Precipitation Processes. KONA Powder Part. J. 2016, 33, 127-149. [CrossRef]

77. Cardoso, F.a.R.; Vogel, E.M.; Souza, M.F.; Cardozo-Filho, L. Mathematical Modeling to Predict the Size and Nucleation Rate of

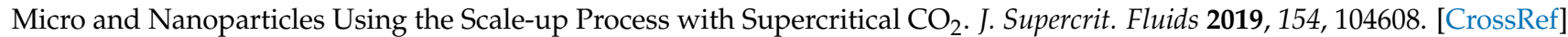

78. Dukhin, S.S.; Shen, Y.; Dave, R.; Pfeffer, R. Development in Modeling Submicron Particle Formation in Two Phases Flow of Solvent-Supercritical Antisolvent Emulsion. Adv. Colloid Interface Sci. 2007, 134-135, 72-88. [CrossRef]

79. Kumar, R.; Thakur, A.K.; Banerjee, N.; Chaudhari, P. Investigation on Crystallization Phenomena with Supercritical Carbon Dioxide $\left(\mathrm{CO}_{2}\right)$ as the Antisolvent. Int. J. Chem. React. Eng. 2021, 19, 861-871. [CrossRef]

80. De Marco, I.; Reverchon, E. Influence of Pressure, Temperature and Concentration on the Mechanisms of Particle Precipitation in Supercritical Antisolvent Micronization. J. Supercrit. Fluids 2011, 58, 295-302. [CrossRef]

81. Mihalovits, M.; Horvath, A.; Lorincz, L.; Szekely, E.; Kemeny, S. Model Building on Selectivity of Gas Antisolvent Fractionation Method Using the Solubility Parameter. Period. Polytech.-Chem. Eng. 2019, 63, 294-302. [CrossRef]

82. Mihalovits, M.; Korosi, M.; Szekely, E. New Formula for the Hydrogen-Bonding Hansen Component of Methanol, Ethanol, and n-Propanol for Non-Ambient Conditions-Application in Gas Antisolvent Fractionation-Based Optical Resolution. ACS Omega 2021, 6, 18964-18974. [CrossRef] [PubMed] 
83. Pasca, M.B.; Pallag, A.; Gitea, D. The quantitative determination of active principles from Calendula officinalis L. Inflorescences 2013, XII, 317-320.

84. Ferreira, C.; Pereyra, A.; Patriarca, A.; Mazzobre, M.; Polak, T.; Abram, V.; Buera, M.; PoklarUlrihd, N. Phenolic Compounds in Extracts from Eucalyptus Globulus Leaves and Calendula officinalis Flowers. J. Nat. Prod. Resour. 2016, 2, 53-57.

85. Zhang, K.; Sun, W.; Fahr, A.; Zeng, X.; Ge, L.; Chen, M.; Yang, L.; Wu, S.; Fei, J.; Zhou, B. Skin-Permeating Components of Lonicera Japonica Flos: A Comprehensive Study from Observations and Model Computations. New J. Chem. 2019, 43, 12538-12547. [CrossRef]

86. Farrell, T.L.; Poquet, L.; Dew, T.P.; Barber, S.; Williamson, G. Predicting Phenolic Acid Absorption in Caco-2 Cells: A Theoretical Permeability Model and Mechanistic Study. Drug Metab. Dispos. 2012, 40, 397-406. [CrossRef]

87. Mortele, O.; Jorissen, J.; Spacova, I.; Lebeer, S.; van Nuijs, A.L.N.; Hermans, N. Demonstrating the Involvement of an Active Efflux Mechanism in the Intestinal Absorption of Chlorogenic Acid and Quinic Acid Using a Caco-2 Bidirectional Permeability Assay. Food Funct. 2021, 12, 417-425. [CrossRef]

88. Artursson, P.; Palm, K.; Luthman, K. Caco-2 Monolayers in Experimental and Theoretical Predictions of Drug Transport. Adv. Drug Deliv. Rev. 1996, 22, 67-84. [CrossRef]

89. Sugino, M.; Todo, H.; Suzuki, T.; Nakada, K.; Tsuji, K.; Tokunaga, H.; Jinno, H.; Sugibayashi, K. Safety Prediction of Topically Exposed Biocides Using Permeability Coefficients and the Desquamation Rate at the Stratum Corneum. J. Toxicol. Sci. 2014, 39, 475-485. [CrossRef]

90. Kimura, E.; Kawano, Y.; Todo, H.; Ikarashi, Y.; Sugibayashi, K. Measurement of Skin Permeation/Penetration of Nanoparticles for Their Safety Evaluation. Biol. Pharm. Bull. 2012, 35, 1476-1486. [CrossRef] 